This document is confidential and is proprietary to the American Chemical Society and its authors. Do not copy or disclose without written permission. If you have received this item in error, notify the sender and delete all copies.

\title{
Designed glycopeptidomimetics disrupt protein-protein interactions mediating amyloid $\beta$-peptide aggregation and restore neuroblastoma cell viability
}

\begin{tabular}{|c|c|}
\hline Journal: & Journal of Medicinal Chemistry \\
\hline Manuscript ID & jm-2015-016292.R1 \\
\hline Manuscript Type: & Article \\
\hline Date Submitted by the Author: & $\mathrm{n} / \mathrm{a}$ \\
\hline Complete List of Authors: & 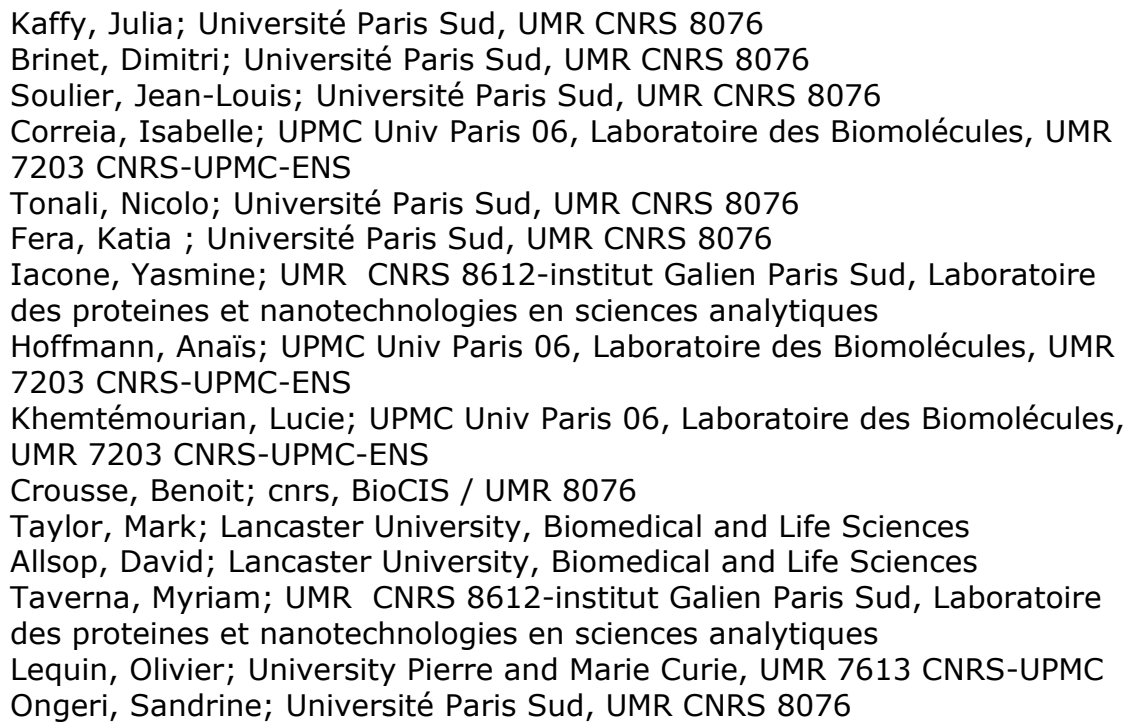 \\
\hline
\end{tabular}




\section{Designed glycopeptidomimetics disrupt protein-} protein interactions mediating amyloid $\beta$-peptide aggregation and restore neuroblastoma cell viability

Julia Kaffy, ${ }^{1}$, Dimitri Brinet ${ }^{1,2}$, Jean-Louis Soulier ${ }^{1}$, Isabelle Correia ${ }^{3}$, Nicolo Tonali ${ }^{1}$, Katia Fabiana Fera ${ }^{1}$, Yasmine Iacone ${ }^{1,2}$, Anaïs R. F. Hoffmann ${ }^{3}$, Lucie Khemtémourian ${ }^{3}$, Benoit Crousse $^{l}$, Mark Taylor ${ }^{4}$, David Allsop ${ }^{4}$, Myriam Taverna,${ }^{2}$ Olivier Lequin ${ }^{3}$, Sandrine Ongeri ${ }^{2}$

\footnotetext{
${ }^{1}$ Molécules Fluorées et Chimie Médicinale, BioCIS, Univ. Paris-Sud, CNRS, Université Paris Saclay, 5 rue Jean-Baptiste Clément, 92296 Châtenay-Malabry Cedex, France

${ }^{2}$ Protéines et Nanotechnologies en Sciences Séparatives, Institut Galien Paris-Sud, Univ. ParisSud, CNRS, Université Paris Saclay, 5 rue Jean-Baptiste Clément, 92296 Châtenay-Malabry Cedex, France
}

\footnotetext{
${ }^{3}$ Sorbonne Universités - UPMC Univ Paris 06, Ecole Normale Supérieure - PSL Research University, CNRS UMR 7203 LBM, 4 place Jussieu, 75252 Paris Cedex 05, France

${ }^{4}$ Lancaster University, Division of Biomedical and Life Sciences, Faculty of Health and Medicine, Lancaster LA1 4YQ, UK
} 
KEYWORDS. amyloid $\beta$-peptide, Alzheimer's disease, peptidomimetics, glycopeptides, aggregation, oligomers, capillary electrophoresis, nuclear magnetic resonance, surface plasmon resonance

\begin{abstract}
How anti-Alzheimer's drug candidates that reduce amyloid 1-42 peptide fibrillization interact with the most neurotoxic species is far from being understood. We report herein the capacity of sugar-based peptidomimetics to inhibit both $A \beta_{1-42}$ early oligomerization and fibrillization. A wide range of bio- and physico-chemical techniques, such as a new capillary electrophoresis method, nuclear magnetic resonance, and surface plasmon resonance, were used to identify how these new molecules can delay the aggregation of $A \beta_{1-42}$. We demonstrate that these molecules interact with soluble oligomers in order to maintain the presence of non-toxic monomers and to prevent fibrillization. These compounds totally suppress the toxicity of $A \beta_{1-42}$ towards SH-SY5Y neuroblastoma cells, even at sub-stoichiometric concentrations. Furthermore, demonstration that the best molecule combines hydrophobic moieties, hydrogen bond donors and acceptors, ammonium groups and a hydrophilic $\beta$-sheet breaker element, provides valuable insight for the future structure-based design of inhibitors of $A \beta_{1-42}$ aggregation.
\end{abstract}

\title{
INTRODUCTION
}

Protein-protein interactions mediating protein aggregation concern at least 30 different proteins and are associated with more than 20 serious human diseases, including Alzheimer's (AD), Parkinson's disease and type 2 diabetes mellitus. The accumulation of extra- or intracellular 
protein deposits, often referred to as amyloid, characterize these protein misfolding diseases. AD, which is the most common form of late-life dementia, ${ }^{1}$ is associated with accumulation of intraneuronal neurofibrillary tangles and extracellular 'senile' plaques containing insoluble fibrils composed of 40 or 42 -residue amyloid- $\beta$ peptides $\left(A \beta_{1-40}\right.$ or $\left.A \beta_{1-42}\right){ }^{2}$ Monomeric $A \beta$ peptides convert into fibrils through a complex nucleation process involving the formation of various aggregated species such as soluble oligomers and protofibrils of increasing size..$^{3-5}$ Structural studies have reported that oligomeric and fibrillar species share a $\beta$-sheet rich conformation, ${ }^{6-10}$ however the structure of the different oligomeric species is far from being understood. Although $A \beta_{1-42}$ is not the most abundant amyloid peptide produced in vivo, it is the major constituent of amyloid plaques and is far more aggregative and neurotoxic than $A \beta_{1-40 .}{ }^{11,12}$ Experimental evidence supports the hypothesis that low molecular weight oligomers are primarily responsible for the neurodegeneration observed in AD.,11,13-16 However, the role of fibrils should not be neglected, because they have been demonstrated not to be inert species, but are able to generate damaging redox activity and promote the nucleation of toxic oligomers. ${ }^{17,18}$ Hence it remains crucial to develop inhibitors that can reduce the prevalence of small transient oligomers and also prevent the formation of fibrils. Numerous compounds have been reported as inhibitors or modulators of $A \beta_{1-42}$ aggregation. The main drawbacks of the described molecules that jeopardize their development as drug candidates are: a lack of binding selectivity leading to a high risk for various side-effects for dyes or polyphenol natural products ${ }^{19}$; poor bioavailability and high propensity to self-aggregate for peptide derivatives ${ }^{20,21}$; and a general lack of information regarding their mechanism of action, and in particular on their effects on toxic oligomers formation. ${ }^{19-21}$ To our knowledge, rationally designed small and 'druggable' pseudo- 
or non-peptidic aggregation inhibitors have been very scarcely reported. ${ }^{22,23}$ Some of us have described retro-inverso peptide inhibitors of both early oligomerization and fibrillization. ${ }^{22}$

We previously reported a novel class of glycopeptide derivatives, based on two hydrophobic dipeptides (Ala-Val and Val-Leu) linked to a hydrophilic D-glucopyranosyl scaffold through aminoalkyl and carboxyethyl linkers in $\mathrm{C} 1$ and $\mathrm{C} 6$ positions, respectively (compound 1, Figure $1){ }^{24}$ These pentapeptide analogs were shown to modulate $A \beta_{1-40}$ and $A \beta_{1-42}$ aggregation, as demonstrated by fluorescence Thioflavin-T (ThT) assays and transmission electron microscopy (TEM). ${ }^{24}$ The flexible and hydrophilic sugar moiety is believed to act as a $\beta$-sheet breaker, playing a major role in preventing the interactions between $A \beta$ species and thus inhibiting the aggregation. The introduction of a carbohydrate in peptides can also have a multifaceted impact on the properties of these molecules, such as modulating the hydrophilicity/hydrophobicity balance and conferring resistance to proteolytic cleavage. ${ }^{25}$

In order to further decrease the number of potential sites for proteolytic attack, we have now introduced peptidomimetics in the upper arm in the C6 position. A wide range of bio- and physico-chemical techniques was then used in order to evaluate the activity of the synthesized small hydrosoluble peptidomimetic compounds on the early oligomerization, fibrillization and toxicity of $A \beta_{1-42}$ and also to identify the $A \beta_{1-42}$ species targeted by these molecules.

\section{RESULTS}

\section{Design}

As we have already demonstrated the superiority of the $\beta$ configuration of the $\mathrm{C} 1$ anomeric carbon in our previously reported glycopeptides, ${ }^{24 \mathrm{~b}}$ we decided in a first attempt to evaluate the mixture of $\alpha$ and $\beta$ anomers, to avoid a difficult separation of the two anomers. Furthermore, as 
we have also clearly demonstrated the superiority of the amino propyloxy link relative to the amino ethyloxy link, in the $\mathrm{C} 1$ position of the sugar moiety, ${ }^{24 \mathrm{~b}}$ we decided to prepare glycopeptidomimetics bearing the amino propyloxy link. For the design of the peptidomimetic strands, we chose to replace the $C$-terminal leucine (Leu5 in compound 1, Figure 1) by the 5amino-2-methoxybenzhydrazide unit (compounds $\mathbf{2}$ and $\mathbf{3}$, Figure 1), which is a part of the $\beta$ strand mimic ("Hao" unit) reported by Nowick and co-workers. ${ }^{21,26}$ The introduction of a 5amino-2-methoxybenzhydrazide unit into $\beta$-strand mimics was shown, by some of us, to be extremely effective in the prevention of protein-protein interactions involving intermolecular $\beta$ sheets of HIV-1 protease in order to inhibit its dimerization, while increasing the proteolytic stability of the molecules. ${ }^{27}$ In a first generation, the valine residue (Val4 in compound 1, Figure 1) was kept and linked to the 5-amino-2-methoxybenzhydrazide unit (compound 2, Figure 1). Next, the valine residue was replaced by a lysine residue, to further provide these molecules with the possibility of engaging in electrostatic interactions with $A \beta_{1-42}$, in order to increase their affinity for $\mathrm{A} \beta_{1-42}$ (compound $\mathbf{3}$, Figure 1). 

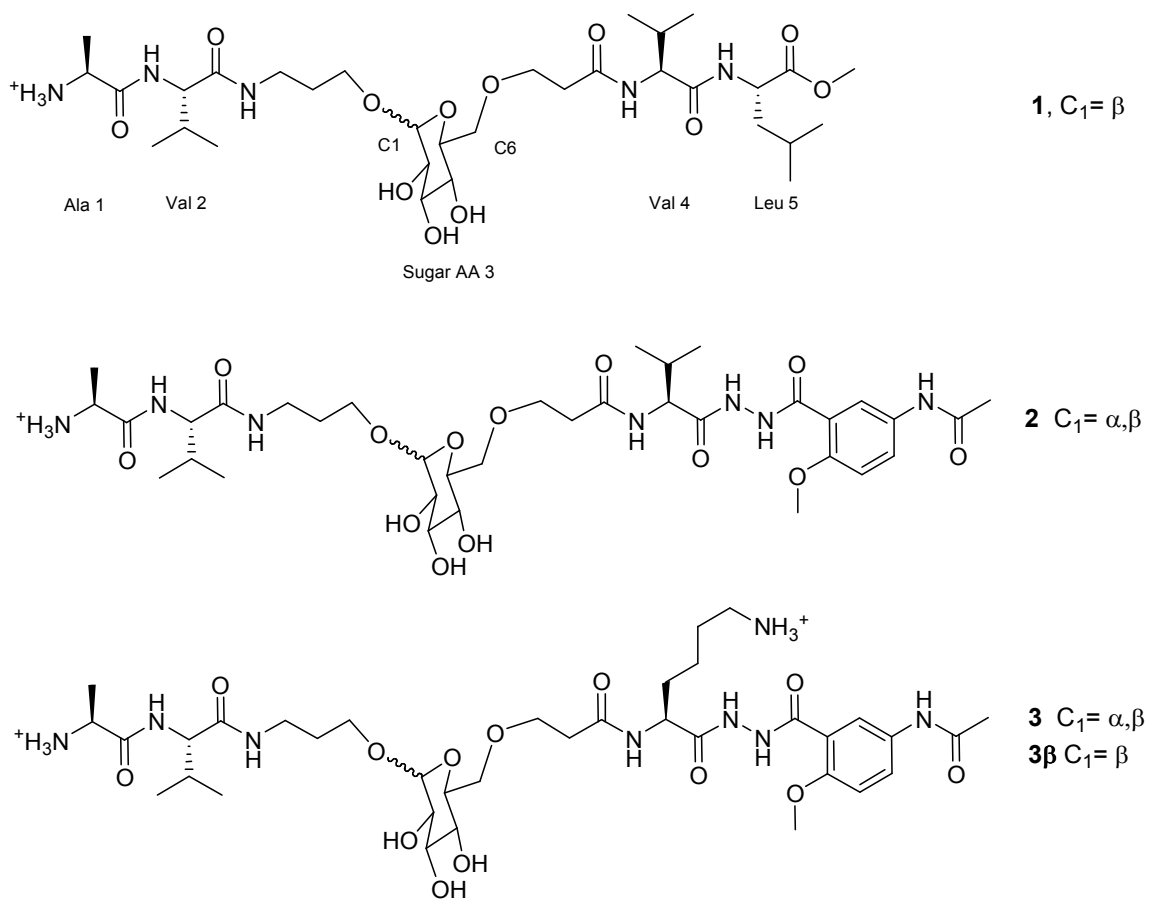

Figure 1. Structure of glycopeptidomimetic derivatives 1-3

\section{Synthesis of the glycopeptidomimetics}

A short and robust synthesis of the intermediate 9 was developed (Scheme 1A). We started from the $\mathrm{C} 1$ allylic protected D-glucose which was transformed into 4 following the procedure described in the literature. ${ }^{28}$ The Michael addition of $\mathbf{4}$ on tert-butylacrylate was performed to give 5. The allyl group of $\mathbf{5}$ was then removed from the $\mathrm{C} 1$ hydroxyl group with $\mathrm{PdCl}_{2}$ to give compound $\mathbf{6}$ in good yield. The anomeric hydroxyl of $\mathbf{6}$ was converted into the trichloroacetimidate intermediate $\mathbf{7}$, in the presence of trichloroacetonitrile and using $\mathrm{NaH}$ as a base. The nucleophilic substitution reaction by 3-azidopropan-1-ol was then carried out in the presence of $\mathrm{AuCl}(10 \%)$ affording 8 in good yield. The $\alpha$ and $\beta$ epimers 8 were obtained in equal proportion and could not be separated at this stage. The tert-butyl group was finally cleaved in acidic conditions to give the carboxylic acid 9. 
The scaffold $\mathbf{9}$ was then coupled with the peptidomimetic arms $\mathbf{1 0}$ and $\mathbf{1 1}$ prepared according to our published procedure ${ }^{27}$, using DMTMM ([4-(4,6-Dimethoxy1,3,5-triazin-2-yl)-4-methylmorpholinium tetrafluoroborate]) ${ }^{29}$ as coupling agent (Scheme 1B). Compounds $\mathbf{1 2}$ and $\mathbf{1 3}$ were obtained in good yield. The azido group of $\mathbf{1 2}$ and $\mathbf{1 3}$ was then reduced via a Staudinger reaction $^{30}$ to give the corresponding amines, $\mathbf{1 4}$ and $\mathbf{1 5}$ in satisfactory yields. In order to build the peptidic arm in $\mathrm{C} 1$, the two amino acids $N$-Boc-L-Val-OH and $N$-Boc-L-Ala-OH were successively coupled by a standard coupling/deprotection protocol to afford $\mathbf{1 8}$ and $\mathbf{1 9}$ from 14 and 15 respectively, in good yields. Hydrogenolysis of 18 and 19 afforded 20 and 21, which underwent an acidic cleavage of the tert-butyl carbamate to give $\mathbf{2}$ and $\mathbf{3}$. The acidic cleavage of the tert-butyl carbamate was also performed on benzylated compounds $\mathbf{1 8}$ and $\mathbf{1 9}$ to afford 22 and 23. All the desired compounds were obtained as a mixture of $\alpha$ and $\beta$ anomers. The $\beta$ anomer $\mathbf{3 \beta}$ was isolated after separation by HPLC.

A
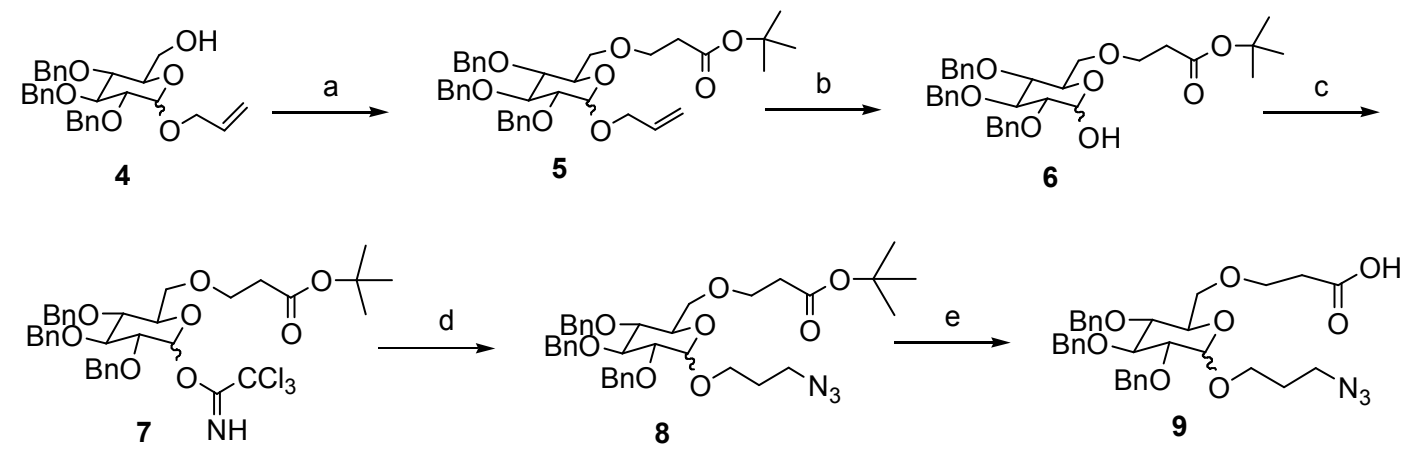

B 

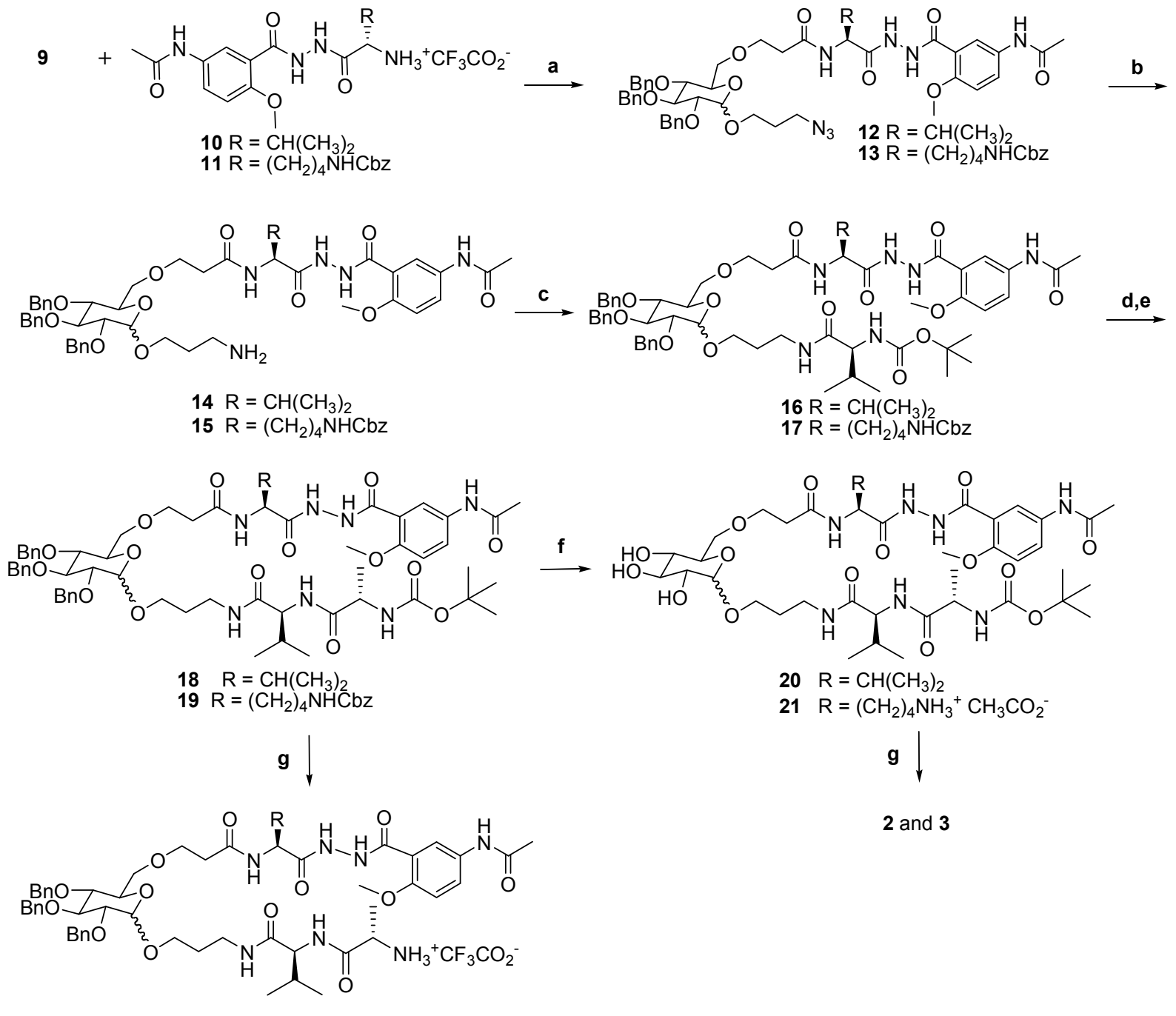

2 and 3

$22 \mathrm{R}=\mathrm{CH}\left(\mathrm{CH}_{3}\right)$

$23 \mathrm{R}=\left(\mathrm{CH}_{2}\right)_{4} \mathrm{NHCbz}$

Scheme 1. Synthesis of glycopeptidomimetics. A- Synthesis of the scaffold 9. Reagents and conditions: a) tert-butyl acrylate, TBAB, 20\% $\mathrm{NaOH}$ aq., rt, 24h, 79\%; b) $\mathrm{PdCl}_{2}, \mathrm{CH}_{3} \mathrm{OH} / \mathrm{EtOH}$, $\mathrm{N}_{2}$ atm. rt, overnight $75 \%$; c) $\mathrm{CCl}_{3} \mathrm{CN}, \mathrm{NaH}, \mathrm{CH}_{2} \mathrm{Cl}_{2}$, rt, overnight, 75\%; d) 3-azidopropan-1-ol, $\mathrm{AuCl}(10 \% \mathrm{w} / \mathrm{w}), \mathrm{CH}_{2} \mathrm{Cl}_{2}, \mathrm{~N}_{2}$ atm., rt, 2 days, $82 \%$; e) TFA, $\mathrm{CH}_{2} \mathrm{Cl}_{2}$, rt, overnight, 72\%. BSynthesis of glycopeptidomimetics 2 and 3. Reagents and conditions: a) NMM, DMTMM, DMF, rt, overnight, 86\% (12), 68\%, (13); b) $\mathrm{Ph}_{3} \mathrm{P}, \mathrm{THF} / \mathrm{H}_{2} \mathrm{O}$ (9:1), $40{ }^{\circ} \mathrm{C}, 24 \mathrm{~h}, 63 \%$ (14), 50\% (15); c) N-Boc-L-Val-OH, NMM, DMTMM, DMF, rt, overnight, 79\% (16), 68\% (17); d) TFA, $\mathrm{CH}_{2} \mathrm{Cl}_{2}$, 


\author{
rt, 3h, quantitative; e) N-Boc-L-Ala-OH, NMM, DMTMM, rt, overnight, 68\% (18), 73\% (19); f) \\ $\mathrm{H}_{2} \mathrm{Pd} / \mathrm{C}$, rt, $\mathrm{MeOH}, 48 \mathrm{~h}, 88 \%$ (20); 75\% (21); g) TFA, $\mathrm{CH}_{2} \mathrm{Cl}_{2}$, rt, 3h, quantitative.
}

\title{
Inhibition of $A \beta_{1-42}$ fibrillization by glycopeptidomimetics
}

\section{ThT-fluorescence assays}

The ability of compounds 1-3 and of intermediates 19-23 to inhibit the fibrillization of $A \beta_{1-42}$ was studied by ThT fluorescence spectroscopy. ${ }^{31}$ The fluorescence curve for $A \beta_{1-42}$ at a concentration of $10 \mu \mathrm{M}$ followed the typical sigmoidal pattern with a lag phase of $8-9 \mathrm{~h}$ followed by an elongation phase and a final plateau reached after 17-18 h (purple curve, Figure 2A). Two parameters were derived from the ThT curves of $A \beta_{1-42}$ alone and $A \beta_{1-42}$ in the presence of the evaluated compound: (1) $t_{1 / 2}$, which is defined as the time at which the half maximal ThT fluorescence is observed and gives insight on the rate of the aggregation process; (2) F, the fluorescence intensity at the plateau which is assumed to be dependent on the amount of fibrillar material formed (Table 1, Figures 2A-C).

The glycopeptidomimetic molecules $\mathbf{2}$ and $\mathbf{3}$ were dramatically more efficient inhibitors of $\mathrm{A} \beta_{1-42}$ aggregation than the glycopeptide compound $\mathbf{1}$ in particular at lower compound/ $A \beta_{1-42}$ ratios of $1 / 1$ and even $0.1 / 1$. It is noteworthy that a lysine residue attached to the 5-amino-2methoxybenzhydrazide unit was highly beneficial for the activity compared to a valine residue (compare $\mathbf{3}$ vs $\mathbf{2}$ and $\mathbf{2 1}$ vs 20). The free amine of the lysine residue side chain is thus beneficial for the activity. However, no dramatic effect of the $N$-terminal free amine of the dipeptide ValAla chain was observed in both lysine and valine series. Indeed, a similar activity was obtained for the free amine $\mathbf{3}$ and the Boc protected $\mathbf{2 1}$ from one hand and for the free amine $\mathbf{2}$ and the Boc protected $\mathbf{2 0}$ on the other hand. It was also remarkable that the $\beta$ anomer $\mathbf{3} \boldsymbol{\beta}$ showed a superior activity to the mixture of $\alpha$ and $\beta$ anomers in 3 at low compound/A $\beta_{1-42}$ ratios $(1 / 1$ and 
0.1/1, Table 1 and Figures 2A-C). A supplementary ThT fluorescence assay was performed by first, adding compound $\mathbf{3}$ after 4 hours, when presumably oligomers are already formed and secondly, adding compound $\mathbf{3}$ after 42 hours, when presumably essentially fibrils are present (Figure 1S in supporting information). A similar activity was obtained with compound $\mathbf{3}$ added at the beginning of the kinetics or after 4 hours. However no effect (or even a slightly increase of fluorescence) was observed when compound $\mathbf{3}$ was added after 42 hours. As also observed in our previous glycopeptides series, ${ }^{24 \mathrm{~b}}$ benzylated derivatives $\mathbf{1 9}$, and $\mathbf{2 2 - 2 3}$ tended to self-aggregate and to slightly accelerate the aggregation process (Table $3 \mathrm{~S}$ and Figure $1 \mathrm{~S}$ in supporting information), confirming that polar hydroxyl groups of the sugar moiety were essential to prevent the aggregation.

Table 1. Effects of compounds $\mathbf{1}, \mathbf{2}, \mathbf{3}, \mathbf{3 \beta}, \mathbf{2 0}$ and $\mathbf{2 1}$ on $\mathrm{A} \beta_{1-42}$ fibrillization assessed by ThTfluorescence spectroscopy at a compound/A $\boldsymbol{\beta}_{1-42}$ ratio of $10 / 1$ and $1 / 1$ (the concentration of $A \beta_{1 \text { - }}$ 42 in this assay is $10 \mu \mathrm{M})$. The effect of $\mathbf{3}$ and $\mathbf{3 \beta}$ at a compound/A $\beta$ ratio of $0.1 / 1$ is also reported.

\begin{tabular}{lll}
\hline $\begin{array}{l}\text { Compounds } \\
\text { (Compound/A } \beta \text { ratio) }\end{array}$ & $\begin{array}{l}t_{1 / 2} \\
\text { increase }\end{array}$ & Plateau \\
& $\begin{array}{l}\text { decrease }(\%) \\
{[\mathrm{b}]}\end{array}$ \\
\hline $\mathbf{1} 10 / 1$ & $280 \pm 70$ & $-56 \pm 9$ \\
$\mathbf{1} 1 / 1$ & ne & ne \\
$\mathbf{2} 10 / 1$ & $325 \pm 12$ & $-31 \pm 7$ \\
$\mathbf{2} 1 / 1$ & $155 \pm 10$ & ne \\
& & \\
$\mathbf{3} 10 / 1$ & NA & $-87 \pm 1$
\end{tabular}




\begin{abstract}
ne $=$ no effect, NA $=$ no aggregation, parameters are expressed as mean $\pm \mathrm{SE}, \mathrm{n}=3-6$. [a] See supporting information for the calculation of the $t_{1 / 2}$ increase. A compound displaying a $t_{1 / 2}$ increase $>100 \%$ is a delayer of aggregation. [b] See supporting information for the calculation of the plateau decrease.
\end{abstract}



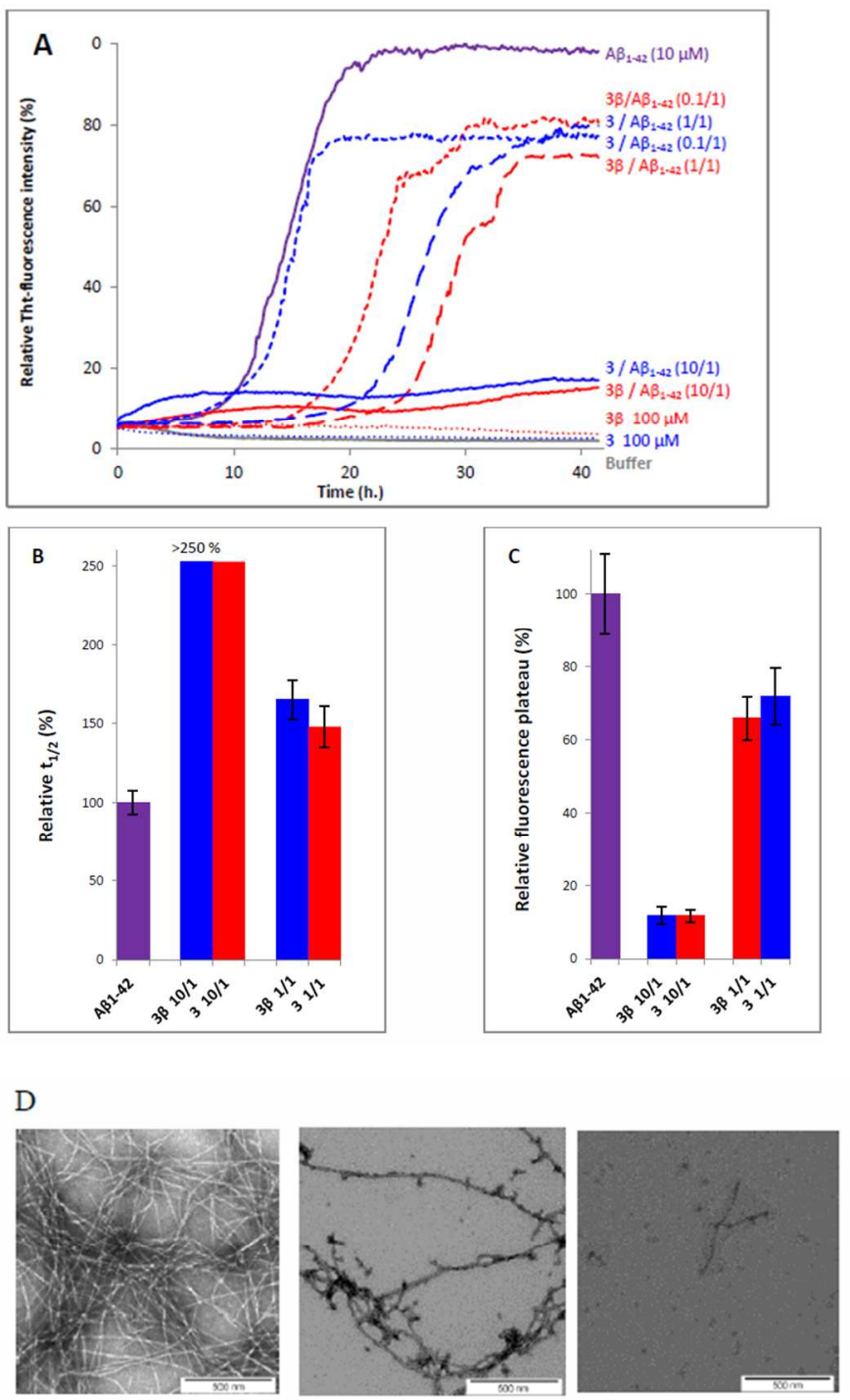

Figure 2. Effects of derivatives $\mathbf{3}$ and $\mathbf{3} \boldsymbol{\beta}$ on the fibrillization kinetics of $A \beta_{1-42}$ monitored by Thioflavin-T fluorescence and TEM. A) Representative curves of ThT fluorescence assays over time showing $A \beta_{1-42}(10 \mu \mathrm{M})$ aggregation in the absence (purple curve) and in the presence of compounds 3 (blue curves) and $\mathbf{3 \beta}$ (red curves) at compound/A $\beta_{1-42}$ ratios of 10/1, 1/1 and 0.1/1. B) $t_{1 / 2}$ increase relative to $\mathrm{A} \beta_{1-42}$ alone, in the presence of compounds $\mathbf{3}$ (blue curves) and $\mathbf{3 \beta}$ (red curves) at compound $/ \mathrm{A} \beta_{1-42}$ ratios of $10 / 1$ and 1/1. C) Fluorescence plateau decrease relative to A $\beta 1-42$ alone, in the presence of compounds $\mathbf{3}$ (blue curves) and $\mathbf{3} \boldsymbol{\beta}$ (red curves). D) Effects of derivative 3 on the fibril formation of $A \beta_{1-42}$ visualized by TEM. Negatively stained images were 
recorded after $42 \mathrm{~h}$ of incubation of $\mathrm{A} \beta_{1-42}(10 \mu \mathrm{M}$ in $10 \mathrm{mM}$ Tris. $\mathrm{HCl}, 100 \mathrm{mM} \mathrm{NaCl}$ at $\mathrm{pH}=$ 7.4) alone (left) or in the presence of $10 \mu \mathrm{M}$ of $\mathbf{3}$ (middle) and of $100 \mu \mathrm{M}$ of $\mathbf{3}$ (right). Scale bars, $500 \mathrm{~nm}$.

\section{TEM experiments}

Transmission electron microscopy (TEM) analyses were performed on compound $\mathbf{3}$ that showed a more significant effect than 2 on $A \beta_{1-42}$ aggregation in the ThT-fluorescence assays. Images were recorded after $42 \mathrm{~h}$ of preincubation, corresponding to maximum aggregation in the ThT assays, with and without 3 (Figure 2D). Differences were observed regarding the amount of aggregates formed in the presence of $\mathbf{3}$ at both ratios. A very dense network of fibers displaying a typical morphology was observed for $A \beta_{1-42}$ alone. Only few scattered, very short and scarce fibers were visible on the grid containing the $A \beta$ sample incubated with 3 at 10/1 ratio. This result validated the ThT-fluorescence data, indicating that compound $\mathbf{3}$ dramatically slowed down the aggregation of $A \beta_{1-42}$ (at $3 / A \beta_{1-42}$ ratio of $\left.10 / 1\right)$ and efficiently reduced the amount of typical amyloid fibrils formed. It is noteworthy that even if at a $3 / A \beta_{1-42}$ ratio of $1 / 1$ the fluorescence was not dramatically decreased in the ThT assays, but the morphology of the network observed by TEM was very different and less dense and the sample contained some globular aggregates.

\section{Inhibition of $A \beta_{1-42}$ oligomerization by glycopeptidomimetics \\ Capillary electrophoresis}

In order to determine their effect on small soluble oligomer formation, $\mathbf{3}$ and $\mathbf{3} \boldsymbol{\beta}$ were studied by Capillary Electrophoresis (CE). We recently proposed an improved CE method to monitor easily over time the very early steps of the $A \beta_{1-42}$ oligomerization process. ${ }^{32,24 \mathrm{~b}}$ This technique 
has the advantage of being able to follow three kinds of soluble species, (i) the monomer (peak ES), (ii) different small metastable oligomers grouped under peak ES' and (iii) transient species formed later and which correspond to species larger than dodecamers (peak LS). Aggregation kinetics of $A \beta_{1-42}$ alone showed that over time, the monomer ES peak decreased in favor of the oligomer peaks ES' and LS, and of insoluble species, forming spikes in the profile (Figure 2S in supporting information for the detailed kinetics). At time 0, the monomer peak ES was almost the only visible species, while after $12 \mathrm{~h}$, only a small monomer peak remained and many insoluble aggregates, giving spikes, were present (Figure 3A).

In the presence of $\mathbf{3 \beta}\left(\mathbf{3} \boldsymbol{\beta} / \mathrm{A} \beta_{1-42}\right.$ ratio of $\left.1 / 1\right)$, the electrophoretic profile clearly indicated that the kinetics of aggregation was significantly slowed down. Indeed, $\mathbf{3 \beta}$ maintained dramatically the presence of the monomer (peak ES). In addition, the large oligomer species grouped under the peak LS were still present at $12 \mathrm{~h}$ while they completely disappeared in the control electrophoretic profile (Figure 3B, and Figure 3S in supporting information for the detailed kinetics). The preservation of the monomer was statistically significant, after $12 \mathrm{~h}$, only $19 \%$ remained in the control experiment while $52 \%$ remained in the presence of $\mathbf{3 \beta}$ (Figure $3 \mathrm{C}$ ). Similar results were observed with the mixture of $\alpha$ and $\beta$ anomers in $\mathbf{3}$, however a slightly superior effect was observed for $\mathbf{3 \beta}$ (41\% of monomer species remained after $12 \mathrm{~h}$ in the presence of the mixture 3) (Figures 4S and 5S in supporting information). 


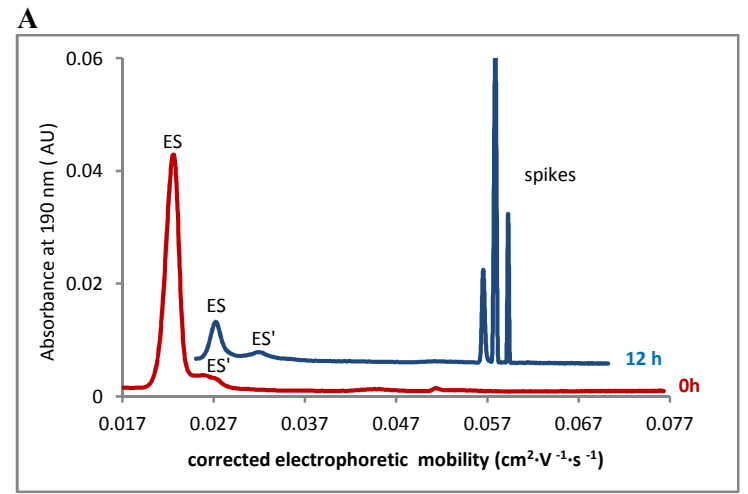

B
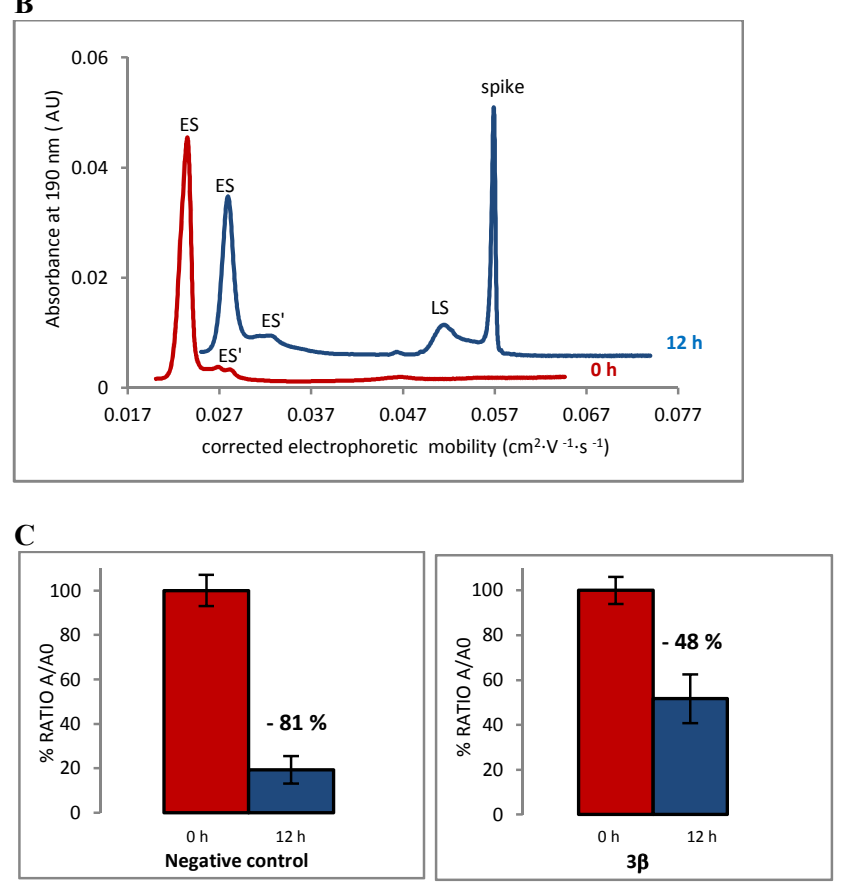

Figure 3. Effect of $\mathbf{3} \boldsymbol{\beta}$ on the early oligomerization steps by CE. Electrophoretic profile of $\mathbf{A} \boldsymbol{\beta}_{\mathbf{1 - 4 2}}$ peptide $(100 \mu \mathrm{M})$ obtained immediately $(0 \mathrm{~h})$, and $12 \mathrm{~h}$ after sample reconstitution (t0) alone (A) and in the presence of compound $\mathbf{3 \beta}$ at compound/A $\boldsymbol{\beta}_{1-42}$ ratio of 1/1 (B). Results in panel show the effect of $\mathbf{3 \beta}$ on the monomer ES (C). Results are a mean of 3 experiments.

\section{Interaction of $3 \beta$ with monomeric or oligomeric species of $A \beta_{1-42}$}

\section{NMR experiments}


The goal of the NMR experiments was to study if compound $\mathbf{3} \boldsymbol{\beta}$ was able to adopt any preferred conformation in solution and if it interacted in solution either with the monomeric species or with soluble aggregated forms of $A \beta_{1-42}$.

We first examined mixtures of $A \beta_{1-42}$ and $3 \boldsymbol{\beta}$ at a temperature of $5^{\circ} \mathrm{C}$ and using low concentrations of $A \beta_{1-42}(10-90 \mu \mathrm{M})$ to ensure that $A \beta_{1-42}$ was mainly monomeric in freshly prepared samples. ${ }^{33}$ The $2 \mathrm{D}{ }^{1} \mathrm{H}_{-}{ }^{15} \mathrm{~N}$ and $2 \mathrm{D}{ }^{1} \mathrm{H}_{-}{ }^{13} \mathrm{C}$ HSQC spectra of $10 \mu \mathrm{M}{ }^{15} \mathrm{~N}$, ${ }^{13} \mathrm{C}$-labelled $\mathrm{A} \beta_{1-42}{ }^{34}$ recorded in the absence and in the presence of a large excess of $3 \beta(0.4 \mathrm{mM})$ displayed no significant chemical shift perturbations of $\mathrm{A} \beta_{1-42}{ }^{1} \mathrm{H}-{ }^{15} \mathrm{~N}$ and ${ }^{1} \mathrm{H}-{ }^{13} \mathrm{C}$ correlations (Figure $6 \mathrm{~S}$ in supporting information). Similarly, no chemical shift differences could be detected for the ${ }^{1} \mathrm{H}$ signals of $3 \boldsymbol{\beta}$ in $1 \mathrm{D}{ }^{1} \mathrm{H}$ and $2 \mathrm{D}{ }^{1} \mathrm{H}-{ }^{1} \mathrm{H}$ experiments (data not shown), even when higher concentrations of $\mathrm{A} \beta_{1-42}$ were used (up to $90 \mu \mathrm{M}$ ). Thus NMR experiments demonstrated that $\mathbf{3 \beta}$ did not interact with monomeric $\mathrm{A} \beta_{1-42}$ peptide.

We then turned to magnetization transfer experiments that are commonly used to detect the binding of small ligands to large molecular weight species. Saturation Transfer Difference (STD) experiments were recorded to characterize binding properties and map binding epitopes of $\mathbf{3 \beta}$. $^{24 a}$ ${ }^{35}$ No STD signals could be detected in a control experiment with $\mathbf{3} \boldsymbol{\beta}$ alone, as expected for a low molecular weight molecule that did not aggregate in solution. The addition of $\mathrm{A} \beta_{1-42}$ peptide led to the apparition of weak STD signals (Figure 4). Interestingly, an increase in the STD signal was observed over time, reaching a maximum after 2.5 weeks. Concomitantly, a slow decay of the $1 \mathrm{D}{ }^{1} \mathrm{H}$ NMR signals of $\mathrm{A} \beta_{1-42}$ was observed (Figure $7 \mathrm{~S}$ in supporting information), corresponding to the formation of high molecular weight $A \beta_{1-42}$ aggregates that were too large to be observed by solution NMR spectroscopy. ${ }^{33}$ Thus the gradual increase of the STD signal over several weeks could be explained by the slow conversion of monomeric $A \beta_{1-42}$ to aggregated 
species that bind $\mathbf{3 \beta}$. The STD signals were the strongest for the aromatic and methyl resonances of $\mathbf{3 \beta}$, suggesting that the hydrophobic groups of the dipeptide and peptidomimetic strands were directly involved in the interaction with $A \beta_{1-42}$ species.

WaterLOGSY experiments also enabled us to detect the binding of $\mathbf{3} \boldsymbol{\beta}$ to $\mathrm{A} \boldsymbol{\beta}_{1-42}$ species, through intermolecular magnetization transfers involving bulk water. The protons of $\mathbf{3 \beta}$ exhibited positive NOEs in the absence of $\mathrm{A} \beta_{1-42}$ (Figure $8 \mathrm{~S}$ in supporting information), as expected for a small molecule. The addition of $A \beta_{1-42}$ caused a decrease of positive NOEs and a change of sign of the NOEs that became more negative over time, confirming that $\mathbf{3} \boldsymbol{\beta}$ binds to high molecular weight species in fast exchange on the NMR time scale.

Finally, NMR spectroscopy was used to analyze the structure of $\mathbf{3 \beta}$ in the free and bound forms. The $1 \mathrm{D}{ }^{1} \mathrm{H}$ NMR spectra of $\mathbf{3 \beta}$ alone were characterized by sharp line widths and concentration-independent chemical shifts (0.04-2 mM range), demonstrating that $\mathbf{3 \beta}$ was highly soluble and not prone to aggregation in the (sub) millimolar range. Chemical shifts, vicinal coupling constants and ROEs analysis showed that the peptidic/pseudopeptidic arms and the aminoalkyl and carboxyethyl linkers were highly flexible, as supported by small diastereotopic splitting of methylenic protons, averaged vicinal coupling constants (Table S1 in supporting information), intraresidual and sequential ROE intensities, and the absence of long-range ROEs. Furthermore the amide protons exhibited strong temperature dependence of their chemical shifts (Table S1 in supporting information), which is an indicator of high solvent accessibility. Altogether, these NMR data indicated that $\mathbf{3 \beta}$ did not adopt per se hydrogen-bonded $\beta$-sheet conformations and had no self-association properties in solution. Interestingly, 2D NOESY experiments recorded on $\mathbf{3} \boldsymbol{\beta}$ in the presence of $A \beta_{1-42}$ were characterized by modifications in the intensity of intraresidual and sequential NOEs which became more negative (Figure 9S in 
supporting information). These changes correspond to transferred NOEs due to transient binding of $\mathbf{3 \beta}$ to $A \beta_{1-42}$ aggregated species. However no additional long-range NOE correlations were detected, suggesting that $\mathbf{3 \beta}$ conformation remained largely extended and did not adopt a compact shape upon $A \beta_{1-42}$ binding.
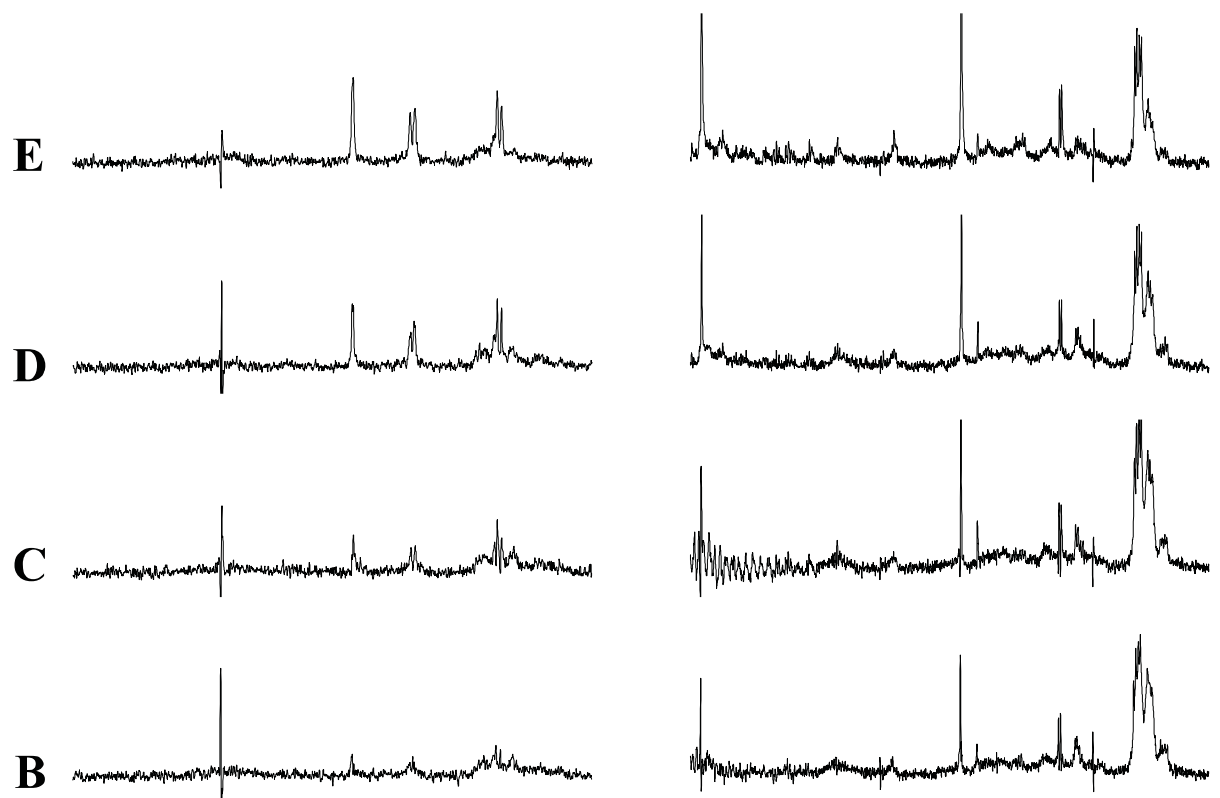

B

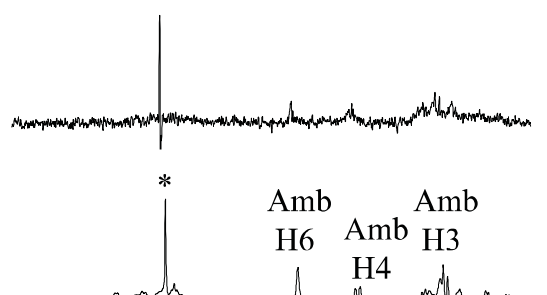

A
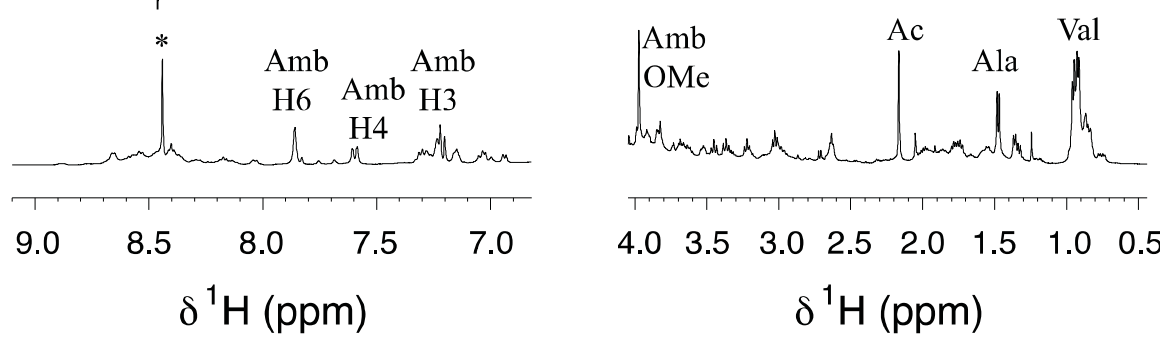

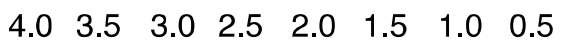

$\delta^{1} \mathrm{H}(\mathrm{ppm})$

Figure 4. Interaction of $\mathbf{3} \boldsymbol{\beta}$ with $\mathrm{A} \beta_{1-42}$ monitored by NMR. Aromatic/amide (left) and aliphatic (right) regions of $1 \mathrm{D}{ }^{1} \mathrm{H}$ NMR spectra of $\mathbf{3 \beta}(0.4 \mathrm{mM})$ and $\mathrm{A} \beta_{1-42}(90 \mu \mathrm{M})$ at $5^{\circ} \mathrm{C}$. (A) Reference $1 \mathrm{D}{ }^{1} \mathrm{H}$ spectrum recorded at $t=0$. (B-E) $1 \mathrm{D}{ }^{1} \mathrm{H}$ STD spectra recorded at $t=0$ (B), after 2 days (C), 1 week (D) and 2.5 weeks (E). The assignment of the aromatic and methyl resonances of $\mathbf{3 \beta}$ is indicated. Amb means 5-amino-2-methoxybenzoyl. The signal marked with an asterisk corresponds to formic acid impurity. 


\section{SPR experiments}

SPR was then used to evaluate the affinity between compound $\mathbf{3}$ and its $\beta$-anomer $\mathbf{3} \boldsymbol{\beta}$ and $\mathrm{A} \beta_{1 \text { - }}$ 42 monomer bound to the gold surface.

To our knowledge, the few SPR experiments described in the literature to detect the affinity of ligands for $A \beta_{1-42}$ have used either the depsi-peptide molecule described by Taniguchi et al. ${ }^{36,37,22}$ or biotinylated $A \beta_{1-42}$ immobilized onto streptavidin-coated chips. ${ }^{38}$ An SPR-based immunoassay has been also developed to recognize $A \beta_{1-42}$ oligomers. ${ }^{39}$ The main drawbacks we found in these methods are the necessity to synthesize the non-commercial depsi-peptide, the modest SPR response provided with these other approaches, and the use of modified peptides which may alter their affinity behavior. We thus developed a new method to immobilize the commercial $A \beta_{1-42}$ peptide monomer by a classical peptide coupling through its amino groups. We paid particular attention to maintaining $A \beta_{1-42}$ in its monomeric form upon immobilization. Recently a similar method has been reported, however no clear evidence on the nature of the immobilized species was provided. $^{40}$

We optimized the immobilization of $\mathrm{A} \beta_{1-42}$ peptide by varying different parameters $(\mathrm{pH}$ and concentration of the sample preparation, and injection parameters such as the flow, the time and the number of injections). To ensure that only monomeric species were mainly immobilized, a rinsing step using an aqueous solution of $\mathrm{NH}_{4} \mathrm{OH} . \mathrm{H}_{2} \mathrm{O} 0.1 \%$ was employed (see the procedure in supporting information), as we demonstrated previously by CE that these conditions were able to disaggregate oligomers and regenerate monomeric species. ${ }^{32}$ The characterization of the gold chip was performed using specific antibodies directed against the $N$ - or $C$-term of $\mathrm{A} \beta_{1-42}(6 \mathrm{E} 10$ and MD 19-0016, respectively, see supporting information). Curcumin, which is a well-known disaggregant compound ${ }^{41}$ did not lead to a decrease of the signal and was even found to bind to 
$\mathrm{A} \beta_{1-42}$ fixed on the SPR chips (Figure $18 \mathrm{~S}$ in supporting information). Finally, the affinity of ThT toward the peptide immobilized on the chip surface was evaluated before and after our optimized rinsing step, which used an aqueous solution of $\mathrm{NH}_{4} \mathrm{OH} . \mathrm{H}_{2} \mathrm{O} 0.1 \%$. Both SPR signal and fluorescence (visualized by fluorescence microscopy images of the channel) were higher before the rinsing step. The rinsing step is therefore crucial to disaggregate large species present initially on the chip surface in order to lead to a surface mainly composed by $A \beta$ in its monomeric form (Figure 14S in supporting information).

We conducted SPR measurements with compounds $\mathbf{3}, \mathbf{3 \beta}$ and $\mathbf{1}$ to check their affinity for A $\beta_{1 \text { - }}$ 42 peptide. A concentration-dependent signal was observed, however, the response was very low in the range of the tested concentrations (up to $200 \mu \mathrm{M}$ ) indicating that these compounds have a very low affinity for the immobilized $A \beta_{1-42}$ (Figures $15 \mathrm{~S}, 16 \mathrm{~S}$ and $17 \mathrm{~S}$ in supporting information). This result is in accordance with the NMR data.

\section{Protection against $A \beta_{1-42}$ cell toxicity}

The inhibitors were investigated to determine their ability to reduce the toxicity of aggregated $\mathrm{A} \beta_{1-42}$ to SH-SY5Y neuroblastoma cells. The addition of either $\mathbf{1}$ or $\mathbf{3}$ showed a protective effect on cell survival (MTS assay, Figure 5) and membrane damage (LDH membrane integrity assay, Figure $19 \mathrm{~S}$ in supporting information) in the presence of cytotoxic $5 \mu \mathrm{M} \mathrm{A} \beta_{1-42}$. Remarkably, this protective effect was seen at equimolar amounts of inhibitor to $A \beta_{1-42}$ and was still significant at a very low ratio of $0.1 / 1$ (inhibitor/A $\beta_{1-42}$ ) in the MTS assay. 
Figure 5. Effect of 1 and 3 on $A \beta_{1-42}$ toxicity towards SH-SY5Y cells. Cell viability in the presence of $5 \mu \mathrm{M}$ aggregated $\mathbf{A} \boldsymbol{\beta}_{1-42}$ and decreasing concentrations of $\mathbf{1}$ or $\mathbf{3}$. The black bar on the left shows cell viability in the absence of $A \beta_{1-42}$. Statistical significance is indicated by *, where $*$ is $\mathrm{p}<0.05, * *$ is $\mathrm{p}<0.01$ and $* * *$ is $\mathrm{p}<0.001$ comparing cells incubated with $\mathbf{A} \boldsymbol{\beta}_{1-42}$ plus inhibitor to those with $\mathbf{A} \boldsymbol{\beta}_{1-42}$ alone. Statistical significance is described.

\section{Plasma stability}

The ability to withstand enzymatic cleavage in the circulatory system is an important requirement for any potential drug. Incubating the two inhibitors $\mathbf{1}$ and $\mathbf{3}$ in plasma gives an idea of how stable they will be once injected into the body. 3 withstood 24 hours at $37^{\circ} \mathrm{C}$ with no obvious degradation in $10 \%$ plasma (Figure $20 \mathrm{~S}$ in supporting information). 1 appeared to show some degradation over the same period, although the total area of the peaks did not change (Figure 20S in supporting information). Unmodified polypeptides are usually degraded within minutes under these incubation conditions. 


\section{DISCUSSION}

The introduction of a peptidomimetic strand based on a 5-amino-2-methoxybenzhydrazide unit linked through the carboxyethyl in the C6 position of the D-glucopyranosyl scaffold not only increased the stability towards proteolytic degradation but also dramatically increased the capacity of these pentapeptide analogs to inhibit the fibrillization of $A \beta_{1-42}$, as demonstrated by the ThT fluorescence and TEM experiments. The polar hydroxyl groups of the sugar moiety were essential to prevent the aggregation, as demonstrated by the lack of inhibitory activity of the benzyl analogues 19, 22-23. A slightly superior effect was observed for the $\beta$ anomer $\mathbf{3 \beta}$ compared to the mixture of $\alpha$ and $\beta$ anomers in $\mathbf{3}$ (confirmed in the $\mathrm{CE}$ experiments). The presence of the amine of the side chain of the lysine residue in compound $\mathbf{3}$ proved to be beneficial for the inhibitory activity in comparison with the valine residue in compound $\mathbf{2}$. This result suggests that an ionic interaction is likely to be established between this amine and acidic residues of $A \beta_{1-42}$, strengthening the hydrophobic interactions involving aliphatic and aromatic moities. Indeed, several computational and experimental studies on $A \beta_{1-42}$ have shown that, in addition to the hydrophobic interactions involving in particular the 16-21 sequence (KLVFFA), the formation of a salt-bridge between amino acids Asp23 and Lys28 might stabilize a turn motif involving residues 24-28, ${ }^{9,42}$ An interaction with Glu22 might also be beneficial for the activity of the molecules. ${ }^{42 \mathrm{~b}}$ We can thus suggest, and this is supported by the NMR binding experiments (STD), that this novel class of glycopeptidomimetics is likely to interact through the hydrophobic sequences of the peptidomimetic and dipeptide sequences, presumably with a hydrophobic sequence of $A \beta_{1-42}$ (such as the central $K_{16}-A_{21}$ or the $C$-terminal part $I_{31}-V_{40}$ ) and through an electrostatic interaction. The flexible and hydrophilic sugar moiety acts as a $\beta$-sheet breaker to prevent the aggregation. The effect of the glycopeptidomimetic on the early steps of 
oligomerization has been also demonstrated clearly by CE. Compound $\mathbf{3} \boldsymbol{\beta}$ dramatically preserved the non-toxic monomer of $\mathrm{A} \beta_{1-42}$ (ES). Oligomers larger than dodecamers (LS) were also stabilized. Both types of cell viability assay proved that pre-incubation of cytotoxic $A \beta_{1-42}$ with glycopeptidomimetic 3 completely rescued the SH-SY5Y neuroblastoma cells. The protective effect was observed even at sub-stoichiometric concentrations ( 3 reduced cell death by 100\% with 0.5 eq and by $75 \%$ with 0.1 eq. in the MTS assay). This protective effect is much more pronounced than that observed with molecules which have undergone clinical trials, such as resveratrol $^{43}$, scyllo-inositol ${ }^{44}$, epigallocatechin-3-gallate $(E G C G)^{44,45}$ or other molecules recently described as efficient reducers of $A \beta_{1-42}$ toxicity. ${ }^{46}$ This effect is comparable to the best effect of the current $A \beta$ aggregation inhibitors reported in the literature. ${ }^{22}$ Indeed, these molecules reduced $A \beta_{1-42}$ toxicity only at stoichiometric or higher (5 to 10 equivalents) concentrations. It is also noteworthy that glycopeptide $\mathbf{1}$ showed a dramatic effect on cell survival, but was more sensitive to proteolytic attack.

The NMR and SPR experiments clearly indicated that this novel glycopeptidomimetic series does not bind to monomers with substantial affinity. NMR indicated that the $A \beta_{1-42}$ species recognized by $\mathbf{3} \boldsymbol{\beta}$ are oligomeric forms whose concentration slowly increased with time. Thus, even if $\mathbf{3 \beta}$ is a small molecule that does not per se adopt a preferential conformation, it is able to recognize and bind to the early $\beta$-structured $A \beta_{1-42}$ oligomers. The observation of magnetization transfers in STD, WaterLOGSY and trNOESY experiments implied that the interconversion between the free and the $A \beta_{1-42}$-bound forms of $\mathbf{3 \beta}$ occurred in fast exchange on the NMR time scale. We can thus hypothesize that such transient binding of $\mathbf{3} \boldsymbol{\beta}$ to oligomers may impede the subsequent addition of monomers or the association of oligomers into larger species and/or disrupt these early oligomers so that they revert back to monomers (Figure 6A). 


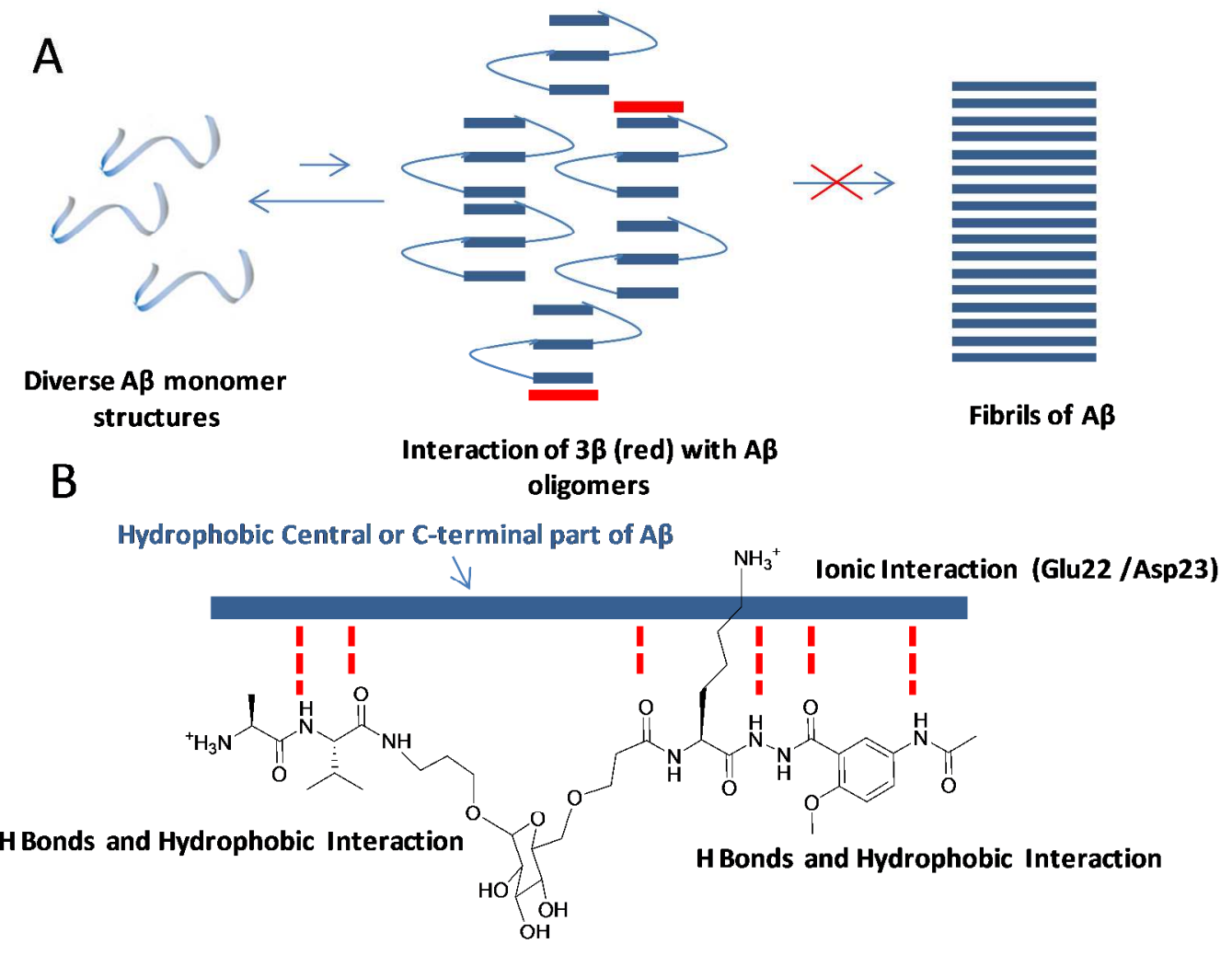

Polar and flexible $\beta$-breaker element:

Prevent association to additional $A \boldsymbol{\beta}$ peptide

Figure 6. Hypothesis of mechanism of $A \beta_{1-42}$ aggregation inhibition by $\mathbf{3 \beta}$. A- Proposed model of inhibition of fibrillization of $A \beta_{1-42}$ and of preservation of $A \beta_{1-42}$ monomer by $\mathbf{3} \boldsymbol{\beta}$. B- Proposed model of interaction of $\mathbf{3 \beta}$ with $A \beta_{1-42}$.

Noteworthy, this inhibition effect is sequence-specific since compound $\mathbf{3}$ does not alter the kinetics of aggregation of another amyloid peptide, IAPP, involved in type 2 diabetes mellitus. Indeed, the peptidomimetic $\mathbf{3}$ does not inhibit the IAPP fibril formation even at a high peptidomimetic/ IAPP ratio of 10/1 (see supporting information). The $t_{1 / 2}$ is not increased after addition of $\mathbf{3}$ and the final fluorescence intensity remains the same. 


\section{CONCLUSION}

In conclusion, the present work validates the singular effect of sugar-based peptidomimetic analogs of pentapeptides on $A \beta_{1-42}$ oligomerization and fibrillization. This new series has been designed in order to achieve three objectives: first, to engage hydrophobic, hydrogen bonds and ionic interactions with $\mathrm{A} \beta_{1-42}$, thanks to small peptide and peptidomimetic arms; secondly, to prevent cross $\beta$-sheet elongation of $A \beta_{1-42}$ due to the hydrophilic sugar, considered as a $\beta$-sheet breaker element (Figure 6B). Finally, it has been designed also to be druggable, particularly to be a small molecule (MW around 800) with a good hydrophobicity/ hydrophilicity balance and resistance to proteolytic degradation. A wide range of bio- and physico-chemical techniques was used to demonstrate the capacity of the compounds (in particular $\mathbf{3 \beta}$ ) to delay both the early oligomerization and fibrillization of $A \beta_{1-42}$. To the best of our knowledge, this is the first example of a small molecule being able to preserve the non-toxic monomeric species of $A \beta_{1-42}$, as demonstrated by capillary electrophoresis. The strong protective effect on cells, even at substoichiometric concentrations, also highlights the considerable therapeutic potential of this novel series of peptidomimetics. This protective effect is significantly better that the one observed with molecules which have undergone clinical trials. The structural elements demonstrated here as crucial for the inhibitory activity, i.e. hydrophobic moieties, hydrogen bond donors and acceptors, ammonium groups and hydrophilic $\beta$-sheet breakers provide valuable insights to explore also the design of compounds targeting other types of amyloid-forming proteins.

\section{EXPERIMENTAL SECTION}

\section{Chemistry}


General Experimental Methods. Usual solvents were purchased from commercial sources and dried and distilled by standard procedures. Compounds $4,^{29} \mathbf{1 0}^{27}$ and $11^{27}$ were prepared according to published methods. Pure products were obtained after liquid chromatography using Merck silica gel $60(40-63 \mu \mathrm{m})$. TLC analyses were performed on silica gel $60 \mathrm{~F}_{250}(0.26 \mathrm{~mm}$ thickness) plates. The plates were visualized with UV light $(\lambda=254 \mathrm{~nm})$ or revealed with a $4 \%$ solution of phosphomolybdic acid in EtOH. Melting points were determined on a Kofler melting point apparatus. Element analyses $(\mathrm{C}, \mathrm{H}, \mathrm{N})$ were performed on a Perkin-Elmer $\mathrm{CHN}$, Analyser 2400 at the Microanalyses Service of the Faculty of Pharmacy at Châtenay-Malabry (BioCIS, France). NMR spectra were recorded on an ultrafield Bruker AVANCE $300\left({ }^{1} \mathrm{H}, 300 \mathrm{MHz},{ }^{13} \mathrm{C}\right.$, $75 \mathrm{MHz})$ or on a Bruker AVANCE $400\left({ }^{1} \mathrm{H}, 400 \mathrm{MHz},{ }^{13} \mathrm{C}, 100 \mathrm{MHz}\right)$. Chemical shifts $\delta$ are in ppm and the following abbreviations are used: singlet (s), doublet (d), doublet of doublet (dd), triplet (t), quintuplet (qt), multiplet (m), broad multiplet (bm), and broad singlet (bs). Mass spectra were obtained using a Bruker Esquire electrospray ionization apparatus. HRMS were obtained using a TOF LCT Premier apparatus (Waters), with an electrospray ionization source. The purity of compounds $\mathbf{2}, \mathbf{1 9 - 2 3}$ was determined by HPLC using the 1260 Infinity system (Agilent Technologies) and a column SUNFIRE (C18, $3.5 \mu \mathrm{m}, 100 \mathrm{~mm} \mathrm{X} 2.1 \mathrm{~mm}$ ); mobile phase : $\mathrm{MeOH} / \mathrm{H}_{2} \mathrm{O}+0.1 \%$ formic acid from 5 to $100 \%$ in $20 \mathrm{~min}$.; detection at $254 \mathrm{~nm}$; flow rate $0.25 \mathrm{~mL} / \mathrm{min}$. The purity of compounds $\mathbf{3}$ and $\mathbf{3 \beta}$ was determined by HPLC using the 1260 Infinity system (Agilent Technologies) and a column SUNFIRE (C18, $5 \mu \mathrm{m}, 150 \mathrm{~mm} \mathrm{X}$ $2.1 \mathrm{~mm}$ ); mobile phase for 3 : acetonitrile $/ \mathrm{H}_{2} \mathrm{O}+0.2 \%$ formic acid from 1 to $100 \%$ in $20 \mathrm{~min}$. ; mobile phase for $\mathbf{3 \beta}$ : acetonitrile $/ \mathrm{H}_{2} \mathrm{O}+0.2 \%$ formic acid at ratio $1 / 99$ during $3 \mathrm{~min}$., then gradient to $30 / 70$ in $12 \mathrm{~min}$; detection at $310 \mathrm{~nm}$; flow rate $0.25 \mathrm{~mL} / \mathrm{min}$. 


\section{$(2 S)-N-[3-[(3 S, 4 S, 5 S)-6-[[3-[[(1 S)-1-[[(5-A c e t a m i d o-2-m e t h o x y-$}

\section{benzoyl)amino]carbamoyl]-2-methyl-propyl]amino]-3-oxo-propoxy]methyl]-3,4,5-}

trihydroxy-tetrahydropyran-2-yl]oxypropyl]-2-[[(2S)-2-aminopropanoyl]amino]-3-methyl-

butanamide (2). Same procedure as described for 16a from 20 (35 mg, $0.036 \mathrm{mmol})$ in dry $\mathrm{CH}_{2} \mathrm{Cl}_{2}(300 \mu \mathrm{L})$ to yield $2(38 \mathrm{mg}$, quantitative, $\alpha / \beta 60 / 40)$ as a white solid. $\mathrm{R}_{\mathrm{f}}=0\left(\mathrm{CH}_{2} \mathrm{Cl}_{2} /\right.$ $\left.\mathrm{CH}_{3} \mathrm{OH}: 95 / 5\right) ;{ }^{1} \mathrm{H}$ NMR $\left(300 \mathrm{MHz}, \mathrm{CD}_{3} \mathrm{OD}\right): \delta=7.88(\mathrm{~d}, J=2.7 \mathrm{~Hz}, 1 \mathrm{H}) ; 7.53(\mathrm{dd}, J=9.0$, $2.7 \mathrm{~Hz}, 1 \mathrm{H}) ; 6.90(\mathrm{~d}, J=9.0 \mathrm{~Hz}, 1 \mathrm{H}) ; 4.54\left(\mathrm{~d}, J=3.6 \mathrm{~Hz}, 0.60 \mathrm{H}, \mathrm{H}_{1 \beta}\right) ; 4.19(\mathrm{~d}, J=7.0 \mathrm{~Hz}, 1 \mathrm{H}$, ) $4.05\left(\mathrm{~d}, J=7.8 \mathrm{~Hz}, 0.40 \mathrm{H}, \mathrm{H}_{1 \alpha}\right) ; 3.96(\mathrm{dd}, J=7.7,2.7 \mathrm{~Hz}, 1 \mathrm{H}) ; 3.86(\mathrm{~m}, 1 \mathrm{H}) ; 3.76(\mathrm{~s}, 3 \mathrm{H}) ; 3.64$ $-2.96(\mathrm{~m}, 12 \mathrm{H}) ; 2.36(\mathrm{~m}, 2 \mathrm{H}) ; 1.96(\mathrm{~m}, 1 \mathrm{H}) ; 1.91(\mathrm{~s}, 3 \mathrm{H}) ; 1.81(\mathrm{~m}, 1 \mathrm{H}) ; 1.58(\mathrm{~m}, 2 \mathrm{H}) ; 1.29(\mathrm{~d}, J$ $=7.0 \mathrm{~Hz}, 3 \mathrm{H}) ; 0.84(\mathrm{~m}, 6 \mathrm{H}) ; 0.74(\mathrm{~d}, J=6.7 \mathrm{~Hz}, 6 \mathrm{H}) ;{ }^{13} \mathrm{C} \mathrm{NMR}\left(75 \mathrm{MHz}, \mathrm{CD}_{3} \mathrm{OD}\right): \delta=174.2$, $174.1,173.0,171.6,171.0,165.5,155.6,133.3,126.8,124.3,120.9,113.4,104.3\left(\mathrm{C}_{1 \mathrm{H} \alpha}\right), 100.2$ $\left(\mathrm{C}_{1 \mathrm{H} \beta}\right), 77.9,76.6,75.0,73.4,72.5,71.6,71.1,68.5,68.4,67.1,60.7,58.7,57.0,50.1,37.8,37.6$, $37.3\left(\mathrm{C}_{8}\right), 31.9,30.0,23.7,19.7,18.7,17.7$; HRMS (TOF, ESI, ion polarity positive, $\mathrm{H}_{2} \mathrm{O}$ / $\mathrm{MeOH}): \mathrm{m} / \mathrm{z}[\mathrm{M}+\mathrm{H}]^{+}$, calcd for $\mathrm{C}_{35} \mathrm{H}_{58} \mathrm{~N}_{7} \mathrm{O}_{13}$ 784.4093; found 784.4094, m/z [M+Na] $]^{+}$, calcd for $\mathrm{C}_{35} \mathrm{H}_{57} \mathrm{~N}_{7} \mathrm{O}_{13} \mathrm{Na}$ 806.3917; found 806.3912; HPLC purity: TR $(\alpha, \beta)=10.91$ min., $95 \%$.

\section{$(2 S)-N-[3-[(3 S, 4 S, 5 S)-6-[[3-[[(1 S)-1-[[(5-A c e t a m i d o-2-m e t h o x y-$}

benzoyl)amino]carbamoyl]-5-amino-pentyl]amino]-3-0xo-propoxy]methyl]-3,4,5trihydroxy-tetrahydropyran-2-yl]oxypropyl]-2-[[(2S)-2-aminopropanoyl]amino]-3-methylbutanamide (3). Same procedure as described for 16a from 21 (38 $\mathrm{mg}, 0.040 \mathrm{mmol}$ ) in dry $\mathrm{CH}_{2} \mathrm{Cl}_{2}(300 \mu \mathrm{L})$ to afford $3(40 \mathrm{mg}$, quantitative, $\alpha / \beta 50 / 50)$ as a white solid. $\mathrm{R}_{\mathrm{f}}=0\left(\mathrm{CH}_{2} \mathrm{Cl}_{2} /\right.$ $\left.\mathrm{CH}_{3} \mathrm{OH}: 95 / 5\right) ;{ }^{1} \mathrm{H}$ NMR $\left(300 \mathrm{MHz}, \mathrm{CD}_{3} \mathrm{OD}\right): \delta=8.16(\mathrm{sl}, 1 \mathrm{H}) ; 7.70(\mathrm{~m}, 1 \mathrm{H}) ; 7.14(\mathrm{~d}, J=9.0$ $\mathrm{Hz}, 1 \mathrm{H}) ; 4.75\left(\mathrm{~m}, 0.50 \mathrm{H}, \mathrm{H}_{1 \beta}\right) ; 4.54(\mathrm{~m}, 1 \mathrm{H}) ; 4.26\left(\mathrm{~d}, J=7.8 \mathrm{~Hz}, 0.50 \mathrm{H}, \mathrm{H}_{1 \alpha}\right) ; 4.14(\mathrm{~m}, 1 \mathrm{H}) ; 4.02$ $(\mathrm{d}, J=7.1 \mathrm{~Hz}, 1 \mathrm{H}) ; 3.98(\mathrm{~s}, 3 \mathrm{H}) ; 3.90(\mathrm{~m}, 1 \mathrm{H}) ; 3.79(\mathrm{~m}, 3 \mathrm{H}) ; 3.70(\mathrm{~m}, 1 \mathrm{H}) ; 3.62(\mathrm{~m}, 2 \mathrm{H}) ; 3.35$ 
$(\mathrm{m}, 4.6 \mathrm{H}) ; 3.16(\mathrm{~m}, 0.6 \mathrm{H}) ; 3.04(\mathrm{~m}, 1 \mathrm{H}) ; 2.98(\mathrm{~m}, 1 \mathrm{H}) ; 2.55(\mathrm{sl}, 2 \mathrm{H}) ; 2.12(\mathrm{~s}, 3 \mathrm{H}) ; 2.03(\mathrm{~m}, 1 \mathrm{H})$

$1.90(\mathrm{~m}, 2 \mathrm{H}) ; 1.77(\mathrm{~m}, 4 \mathrm{H}) ; 1.57(\mathrm{~m}, 2 \mathrm{H}) ; 1.50(\mathrm{~d}, J=7.1 \mathrm{~Hz}, 3 \mathrm{H}) ; 1.34(\mathrm{~d}, J=6.5 \mathrm{~Hz}, 4 \mathrm{H})$;

$0.97(\mathrm{~d}, \mathrm{~J}=6.5 \mathrm{~Hz}, 6 \mathrm{H}) ;{ }^{13} \mathrm{C} \mathrm{NMR}\left(125 \mathrm{MHz}, \mathrm{H}_{2} \mathrm{O}: \mathrm{D}_{2} \mathrm{O} 90: 10\right): \delta=177.5,177.1,175.9$,

$175.6,173.6,169.5,169.2,165.6,158.1,132.8,131.5,131.4,130.18,127.8,121.4$, , 121.2, 120.1,

117.8, 115.6, $104.9\left(\mathrm{C}_{1 \mathrm{H \alpha} \alpha}\right), 103.0,100.9\left(\mathrm{C}_{1 \mathrm{H} \beta}\right), 78.3,77.3,75.8,73.1,72.4,72.1,71.5,70.3$, $69.9,69.8,68.1,63.1,58.8,55.6,55.27,53.5,51.6,47.3,42.1,42.0,39.2,39.0,38.5,38.3,34.1$, $33.2,33.1,32.6,31.1,31.0,29.2,29.1,28.2,25.3,24.9,24.7,21.1,21.0,20.8,19.5$; HRMS (TOF, ESI, ion polarity positive, $\mathrm{H}_{2} \mathrm{O} / \mathrm{MeOH}$ ): $\mathrm{m} / \mathrm{z}[\mathrm{M}+\mathrm{H}]^{+}$, calcd for $\mathrm{C}_{36} \mathrm{H}_{61} \mathrm{~N}_{8} \mathrm{O}_{13} 813.4358$; found 813.4363; HPLC purity: TR $(\alpha, \beta)=11.70$ min., $100 \%$.

$(2 S)-\mathrm{N}-[3-[(2 R, 3 S, 4 S, 5 S)-6-[[3-[[(1 S)-1-[[(5-A c e t a m i d o-2-m e t h o x y-$ benzoyl)amino]carbamoyl]-5-amino-pentyl]amino]-3-oxo-propoxy]methyl]-3,4,5trihydroxy-tetrahydropyran-2-yl]oxypropyl]-2-[[(2S)-2-aminopropanoyl]amino]-3-methylbutanamide (3及). Isolation of $\beta$ anomer $\mathbf{3 \beta}$ from $\mathbf{3}$ was performed by HPLC using a WATERS gradient system pump (DELTAPREP, UV detector PDA 2996) and a column sunfire (C18, 5 $\mu \mathrm{m}, 150 \mathrm{~mm} \times 19 \mathrm{~mm}$ ); mobile phase: acetonitrile $/ \mathrm{H}_{2} \mathrm{O}+0.2 \%$ formic acid at ratio $1 / 99$ during 3 min., then at ratio $60 / 40$ in $12 \mathrm{~min}$. ; flow rate $17 \mathrm{~mL} / \mathrm{min}$. ; detection at $310 \mathrm{~nm}$. HRMS (TOF, ESI, ion polarity positive, $\mathrm{H}_{2} \mathrm{O} / \mathrm{MeOH}$ ): $\mathrm{m} / \mathrm{z}[\mathrm{M}+\mathrm{H}]^{+}$, calcd for $\mathrm{C}_{36} \mathrm{H}_{61} \mathrm{~N}_{8} \mathrm{O}_{13} 813.4358$; found 813.4356 ; HPLC purity: TR $=10.12$ min., $100 \% .{ }^{1} \mathrm{H}$ and ${ }^{13} \mathrm{C}$ NMR assignments are shown in supporting information (Tables S1 and S2)

\section{tert-Butyl 3-[(6-allyloxy-3,4,5-tribenzyloxy-tetrahydropyran-2-yl)methoxy]propanoate}

(5). To a suspension of 4 (7.00 g, $14.27 \mathrm{mmol})$ in tert-butyl-acrylate $(4.14 \mathrm{~mL}, 28.54 \mathrm{mmol})$ was added TBAB (690 mg, $2.14 \mathrm{mmol}$ ) and an aqueous solution of $\mathrm{NaOH} 20 \%(60 \mathrm{~mL})$. The reaction mixture, which appeared like an emulsion, was stirred for $24 \mathrm{~h}$ at room temperature. At 
the end of the reaction, a mixture of EtOAc/ $\mathrm{H}_{2} \mathrm{O} 1 / 1(200 \mathrm{~mL})$ was added and the aqueous phase was extracted with EtOAc $(3 \times 60 \mathrm{~mL})$. The combined organic layers were dried over $\mathrm{Na}_{2} \mathrm{SO}_{4}$, filtered and concentrated under reduced pressure to give a crude oil which was purified by column chromatography on silica gel with eluent cyclohexane/EtOAc 80/20 to afford $\mathbf{5}$ as a colourless oil (7.1 g, 79\%, $\alpha / \beta$ 70/30). $\mathrm{R}_{\mathrm{f}}=0.45$ (cyclohexane/EtOAc : 80/20); ${ }^{1} \mathrm{H}$ NMR $(300$ $\left.\mathrm{MHz}, \mathrm{CDCl}_{3}\right): \delta=7.34(\mathrm{~m}, 15 \mathrm{H}) ; 5.93(\mathrm{~m}, 1 \mathrm{H}) ; 5.32(\mathrm{dd}, J=17.2,1.5 \mathrm{~Hz}, 1 \mathrm{H}) ; 5.22(\mathrm{~d}, J=$ $10.0 \mathrm{~Hz}, 1 \mathrm{H}) ; 4.86\left(\mathrm{~d}, J=4.9 \mathrm{~Hz}, 0.75 \mathrm{H}, \mathrm{H}_{1 \beta}\right) ; 4.45\left(\mathrm{~d}, J=7.8 \mathrm{~Hz}, 0.25 \mathrm{H}, \mathrm{H}_{1 \alpha}\right) ; 5.10-4.54(\mathrm{~m}$, $6 \mathrm{H}), 4.25-3.47(\mathrm{~m}, 10 \mathrm{H}) ; 2.52(\mathrm{t}, J=6.3 \mathrm{~Hz}, 2 \mathrm{H}) ; 1.45(\mathrm{~s}, 9 \mathrm{H}) ;{ }^{13} \mathrm{C} \mathrm{NMR}\left(75 \mathrm{MHz}, \mathrm{CDCl}_{3}\right): \delta$ $=170.7,138.9,138.4,138.2,133.8,128.5,128.4,128.3,128.1,128.0,127.9,127.7,127.5$, $118.2,95.7,82.1,80.5,79.9,77.6,75.7,75.0,73.2,70.2,69.5,68.2,67.1,36.1,28.1$; Anal. Calcd for $\mathrm{C}_{37} \mathrm{H}_{46} \mathrm{O}_{8}$ : C, 71.82; H, 7.49; Found C, 71.75; H, 7.65; MS (ESI, ion polarity positive, $\mathrm{MeOH}): \mathrm{m} / \mathrm{z}: 641.4[\mathrm{M}+\mathrm{Na}]^{+}$.

\section{tert-Butyl 3-[(3,4,5-tribenzyloxy-6-hydroxy-tetrahydropyran-2-yl)methoxy]propanoate}

(6). To a stirred mixture of 5 (7.10 g, $11.47 \mathrm{mmol})$ in $\mathrm{CH}_{3} \mathrm{OH} / \mathrm{EtOH} 2 / 1$ (60 mL) was added $\mathrm{PdCl}_{2}$ (170 mg, mass 2.4\%) at room temperature. The brown suspension was stirred under azote atmosphere overnight and became darker and finally black. The reaction mixture was filtered through a pad of Celite which was washed several times with $\mathrm{CH}_{3} \mathrm{OH}$. The filtrate was then concentrated under reduced pressure to obtain a brown oil, which was purified by column chromatography on silica gel with eluent cyclohexane/EtOAc 90/10 to yield $\mathbf{6}$ as a yellow oil (4.61 g, 75\%, $\alpha / \beta$ 70/30). $\mathrm{R}_{\mathrm{f}}=0.15$ (cyclohexane/EtOAc : 90/10) ; ${ }^{1} \mathrm{H}$ NMR $\left(300 \mathrm{MHz}, \mathrm{CDCl}_{3}\right)$ : $\delta=7.32(\mathrm{~m}, 15 \mathrm{H}) ; 5.32\left(\mathrm{~s}, 0.70 \mathrm{H}, \mathrm{H}_{1 \beta}\right) ; 5.04-4.56\left(\mathrm{~m}, 6.30 \mathrm{H}, 6 \mathrm{H}+\mathrm{H}_{1 \alpha}\right) ; 4.22-3.36(\mathrm{~m}, 8 \mathrm{H}) ; 2.52$ $(\mathrm{t}, J=6.5 \mathrm{~Hz}, 2 \mathrm{H}) ; 1.45(\mathrm{~s}, 9 \mathrm{H}) ;{ }^{13} \mathrm{C} \mathrm{NMR}\left(75 \mathrm{MHz}, \mathrm{CDCl}_{3}\right): \delta=170.7,138.9,138.4,138.2$, 
$128.5,128.4,128.3,128.1,128.0,127.9,127.7,127.5,95.7,82.1,80.5,79.9,77.6,75.7,75.0$, 73.2, 70.2, 69.5, 67.1, 36.1, 28.1; MS (ESI, ion polarity positive, $\mathrm{MeOH}): \mathrm{m} / \mathrm{z}: 601.4[\mathrm{M}+\mathrm{Na}]^{+}$. tert-Butyl 3-[[3,4,5-tribenzyloxy-6-(2,2,2-trichloroethan imidoyl)oxy-tetrahydropyran-2yl]methoxy] propanoate (7). To a solution of $6(4.61 \mathrm{~g}, 7.96 \mathrm{mmol})$ in dry $\mathrm{CH}_{2} \mathrm{Cl}_{2}(80 \mathrm{~mL})$ cooled at $0^{\circ} \mathrm{C}$ was gradually added under azote atmosphere $\mathrm{NaH}(60 \%$ dispersion in mineral oil, $180 \mathrm{mg} ; 4.50 \mathrm{mmol})$. Then trichloroacetonitrile (3.8 mL, $38.06 \mathrm{mmol}, 11$ eq.) was added. After 20 minutes, the ice bath was removed and the reaction mixture was let to stir at room temperature for 4 hours. The solution turned from yellowish to orange while stirring and finally became brown. After stirring overnight, the solvent was evaporated under reduced pressure and the crude residue was purified by column chromatography on neutral alumina with eluent cyclohexane/EtOAc $80 / 20$ to give 7 as a yellow oil $(4.31 \mathrm{~g}, 75 \%, \alpha / \beta 85 / 15) . \mathrm{R}_{\mathrm{f}}=0.45$ (cyclohexane/EtOAc : 80/20) ; ${ }^{1} \mathrm{H}$ NMR $\left(300 \mathrm{MHz}, \mathrm{CDCl}_{3}\right): \delta=8.59(\mathrm{~s}, 1 \mathrm{H}) ; 7.31(\mathrm{~m}, 15 \mathrm{H})$; $6.53\left(\mathrm{~d}, J=3.4 \mathrm{~Hz}, 0.84 \mathrm{H}, \mathrm{H}_{1 \beta}\right) ; 5,03-4.61\left(\mathrm{~m}, 6.16 \mathrm{H}, 6 \mathrm{H}+\mathrm{H}_{1 \alpha}\right) ; 4,27-3.48(\mathrm{~m}, 8 \mathrm{H}) ; 2.51(\mathrm{t}, J=$ $6.6 \mathrm{~Hz}, 2 \mathrm{H}) ; 1,44(\mathrm{~s}, 9 \mathrm{H})$.

\section{tert-Butyl 3-((6-(3-azidopropoxy)-3,4,5-tris(benzyloxy)-tetrahydropyran-2-yl)methoxy)}

propanoate (8). To a stirred solution of 7 (4.31 g, $5.96 \mathrm{mmol})$ and 3-azidopropan-1-ol (723 $\mathrm{mg}$, $7.15 \mathrm{mmol})$ in dry $\mathrm{CH}_{2} \mathrm{Cl}_{2}(15 \mathrm{~mL})$ under azote atmosphere, was added $\mathrm{AuCl}(181 \mathrm{mg}$, mass $10 \%$ ). The reaction mixture was stirred for 2 days at room temperature under azote atmosphere. Upon completion of the reaction monitored by TLC, the mixture was filtered to remove the catalyst and the filtrate was concentrated under reduced pressure. The oily residue afforded was purified by column chromatography on silica gel with eluent cyclohexane/EtOAc 80/20 to give 8 as a yellow oil $(3.25 \mathrm{~g}, 82 \%, \alpha / \beta 50 / 50) . \mathrm{R}_{\mathrm{f}}=0.45$ (cyclohexane/EtOAc : 80/20) $;{ }^{1} \mathrm{H}$ NMR $(300$ $\left.\mathrm{MHz}, \mathrm{CDCl}_{3}\right): \delta=7.33(\mathrm{~m}, 15 \mathrm{H}) ; 5.08-4.55\left(\mathrm{~m}, 6.50 \mathrm{H}, 6 \mathrm{H}+\mathrm{H}_{1 \beta}\right) ; 4.38(\mathrm{~d}, J=7.8 \mathrm{~Hz}, 0.50 \mathrm{H}$, 
$\left.\mathrm{H}_{1 \alpha}\right) ; 4.13-3.23(\mathrm{~m}, 12 \mathrm{H}) ; 2.51(\mathrm{t}, J=6.6 \mathrm{~Hz}, 2 \mathrm{H}) ; 1.91(\mathrm{~m}, 2 \mathrm{H}) ; 1.45(\mathrm{~s}, 9 \mathrm{H}) ;{ }^{13} \mathrm{C} \mathrm{NMR}(75$

$\left.\mathrm{MHz}, \mathrm{CDCl}_{3}\right): \delta=170.8,138.9,138.6,138.4,138.2,128.4,128.3,128.0,127.8,127.6,103.6$

$\left(\mathrm{C}_{1 \mathrm{H \alpha}}\right), 97.2\left(\mathrm{C}_{1 \mathrm{H} \beta}\right), 84.7,82.3,82.0,80.5,80.1,77.8,76.6,75.6,75.1,74.9,73.3,70.4,69.8$, $69.5,67.3,66.6,64.7,48.4,36.3,36.1,29.3,28.9,28.1,27.0 ; \quad$ IR (neat) : $2096\left(\mathrm{~N}_{3}\right) ; 1728$ $(\mathrm{C}=\mathrm{O}) ; 1366\left(\mathrm{CH}_{3}\right) ; 1066(\mathrm{C}-\mathrm{O}) \mathrm{cm}^{-1}$; Anal. Calcd for $\mathrm{C}_{37} \mathrm{H}_{47} \mathrm{~N}_{3} \mathrm{O}_{8} \cdot 0.5 \mathrm{H}_{2} \mathrm{O}: \mathrm{C}, 66.25 ; \mathrm{H}, 7.23$; N, 6.27 Found C, 66.11; H, 7.04; N, 5.81 ; MS (ESI, ion polarity positive, $\mathrm{MeOH})$ : m/z: 684.7 $[\mathrm{M}+\mathrm{Na}]^{+}$.

\section{3-((6-(3-Azidopropoxy)-3,4,5-tris(benzyloxy)-tetrahydropyran-2-yl)methoxy)propanoic}

acid (9). To a stirred solution of $8(3.21 \mathrm{~g}, 4.85 \mathrm{mmol})$ in dry $\mathrm{CH}_{2} \mathrm{Cl}_{2}(40 \mathrm{~mL})$ cooled at $0^{\circ} \mathrm{C}$ was cautiously added TFA $(18.6 \mathrm{~mL}, 250.40 \mathrm{mmol})$. The reaction mixture appeared like a yellow solution and was stirred overnight at room temperature. The day after, the solvent was evaporated under reduced pressure and the crude residue was purified by column chromatography on silica gel beginning with $\mathrm{CH}_{2} \mathrm{Cl}_{2} 100 \%$ as eluent and finishing with an eluent mixture $\mathrm{CH}_{2} \mathrm{Cl}_{2} / \mathrm{CH}_{3} \mathrm{OH} 95 / 5$ to provide 9 as a yellow oil $(2.11 \mathrm{~g}, 72 \%, \alpha / \beta 50 / 50)$. $\mathrm{R}_{\mathrm{f}}=0.40$ $\left(\mathrm{CH}_{2} \mathrm{Cl}_{2} / \mathrm{CH}_{3} \mathrm{OH} 95 / 5\right) ;{ }^{1} \mathrm{H}$ NMR $\left(300 \mathrm{MHz}, \mathrm{CDCl}_{3}\right): \delta=7.32(\mathrm{~m}, 15 \mathrm{H}) ; 6.93(\mathrm{~s}, 1 \mathrm{H}) ; 5.04-$ $4.54\left(\mathrm{~m}, 6.50 \mathrm{H}, 6 \mathrm{H}+\mathrm{H}_{1 \beta}\right) ; 4.40\left(\mathrm{~d}, J=7.8 \mathrm{~Hz}, 0.50 \mathrm{H}, \mathrm{H}_{1 \alpha}\right) ; 4.08-3.32(\mathrm{~m}, 12 \mathrm{H}) ; 2.63(\mathrm{~m}, 2 \mathrm{H})$; 2.03-1.71 (m, 2H) $;{ }^{13} \mathrm{C}$ NMR $\left(75 \mathrm{MHz}, \mathrm{CDCl}_{3}\right): \delta=175.4,138.8,138.5,138.4,138.2,138.1$, 128.4, 128.0, 127.9, 127.6, $103.6\left(\mathrm{C}_{1 \mathrm{H} \alpha}\right), 97.2\left(\mathrm{C}_{1 \mathrm{H} \beta}\right), 84.6,82.2,82.0,80.1,75.7,75.1,74.9$, 74.6, 73.3, 70.2, 69.9, 69.7, 66.6, 64.8, 48.3, 34.7, 34.5, 29.3, 28.9; IR (neat) : $2097\left(\mathrm{~N}_{3}\right) ; 1714$ $(\mathrm{C}=\mathrm{O}) ; 1065(\mathrm{C}-\mathrm{O}) \mathrm{cm}^{-1}$; MS (ESI, ion polarity positive, $\left.\mathrm{MeOH}\right): \mathrm{m} / \mathrm{z}: 629[\mathrm{M}+\mathrm{Na}]^{+}$.

\section{N-[(1S)-1-[[(5-Acetamido-2-methoxy-benzoyl)amino]carbamoyl]-2-methyl-propyl]-3- [[(3S,4S,5S)-3,4,5-tribenzyloxy-6-[3-[(imino-5-azanylidene)amino]propoxy]}

tetrahydropyran-2-yl]methoxy]propanamide (12). To a stirred solution of 10 (360 mg, 0.83 
mmol) in dry DMF (5 mL) and cooled at $0^{\circ} \mathrm{C}$ under azote atmosphere, were successively added DMTMM (270 mg, $0.83 \mathrm{mmol})$ and NMM $(272 \mu \mathrm{L}, 2.48 \mathrm{mmol})$. The reaction mixture was stirred at $0^{\circ} \mathrm{C}$ for $1 \mathrm{~h}$. Then, $9(500 \mathrm{mg}, 0.83 \mathrm{mmol})$ in dry DMF $(5 \mathrm{~mL})$ was added to the reaction mixture. The ice bath was removed after 30 minutes and the orange reaction mixture was stirred at room temperature overnight. The solvent was evaporated under reduced pressure and the oily residue was taken up with EtOAc $(50 \mathrm{~mL})$. The organic layer was successively washed with distilled water, $10 \%$ citric acid aqueous solution, $10 \%$ aqueous $\mathrm{K}_{2} \mathrm{CO}_{3}$ solution and brine, dried over anhydrous $\mathrm{Na}_{2} \mathrm{SO}_{4}$, filtered and concentrated under reduced pressure. The yellow crude product was purified by puriflash column chromatography (SI-HP, 12 g, 22 bars, $30 \mu \mathrm{m}$, flow rate: $20 \mathrm{~mL} / \mathrm{min}$ ) with eluent $\mathrm{CH}_{2} \mathrm{Cl}_{2} / \mathrm{CH}_{3} \mathrm{OH} 95 / 5$ to afford 12 as a white solid (593 $\mathrm{mg}, 86 \%$, $\alpha / \beta 40 / 60) ; \mathrm{mp}=71-73{ }^{\circ} \mathrm{C} ; \mathrm{R}_{\mathrm{f}}=0.60\left(\mathrm{CH}_{2} \mathrm{Cl}_{2} / \mathrm{CH}_{3} \mathrm{OH} 95 / 5\right) ;{ }^{1} \mathrm{H} \mathrm{NMR}\left(300 \mathrm{MHz}, \mathrm{CDCl}_{3}\right): \delta$ $=12.05(\mathrm{t}, J=6.2 \mathrm{~Hz}, 1 \mathrm{H}, \mathrm{NH}) ; 11.28(\mathrm{~d}, J=6.3 \mathrm{~Hz}, 1 \mathrm{H}, \mathrm{NH}) ; 9.80(\mathrm{~s}, 1 \mathrm{H}) ; 8.58(\mathrm{dd}, J=9.1$, $2.4 \mathrm{~Hz}, 1 \mathrm{H}) ; 8.27(\mathrm{~d}, J=2.4 \mathrm{~Hz}, 1 \mathrm{H}) ; 7.33-7.19(\mathrm{~m}, 15 \mathrm{H}) ; 7.07-6.95(\mathrm{~m}, 2 \mathrm{H}) ; 5.30(\mathrm{~m}, 1 \mathrm{H})$; 4.94$4.58\left(\mathrm{~m}, 6.40 \mathrm{H}, 6 \mathrm{H}+\mathrm{H}_{1 \beta}\right) ; 4.40\left(\mathrm{~d}, J=7.8 \mathrm{~Hz}, 0.60 \mathrm{H}, \mathrm{H}_{1 \alpha}\right) ; 4.02-3.44(\mathrm{~m}, 15 \mathrm{H}) ; 2.59(\mathrm{~m}, 2 \mathrm{H})$; $2.19(\mathrm{~s}, 3 \mathrm{H}) ; 2.09-2.01(\mathrm{~m}, 1 \mathrm{H}) ; 1.94-1.83(\mathrm{~m}, 2 \mathrm{H}) ; 0.91-0.96(\mathrm{~m}, 6 \mathrm{H}) ;{ }^{13} \mathrm{C} \mathrm{NMR} \quad(75 \mathrm{MHz}$ $\left.\mathrm{CDCl}_{3}\right): \delta=171.2,171.1,169.0,164.9,158.2,158.1,153.1,138.9,138.6,138.4,138.3,138.2$ $138.1,133.9,128.4,128.3,128.0,127.9,127.8,127.5,124.7,122.5,117.7,111.8,103.6\left(\mathrm{C}_{1 \mathrm{H} \alpha}\right)$, $97.1\left(\mathrm{C}_{1 \mathrm{H} \beta}\right), 84.6,82.3,81.9,80.3,77.8,77.7,75.5,75.1,75.0,74.9,73.1,70.3,70.1,69.7,67.7$, $67.6,66.6,64.8,56.4,55.8,48.3,37.6,37.5,33.4,33.3,29.3,28.9,24.3,18.9,18.2$; IR (neat) : $3375(\mathrm{~N}-\mathrm{H}) ; 2097\left(\mathrm{~N}_{3}\right) \mathrm{cm}^{-1}$; Anal. Calcd for $\mathrm{C}_{48} \mathrm{H}_{59} \mathrm{~N}_{7} \mathrm{O}_{11} \cdot 0.5 \mathrm{H}_{2} \mathrm{O}: \mathrm{C}, 62.73 ; \mathrm{H}, 6.58 ; \mathrm{N}, 10.67$ Found C, 62.78; H, 6.98; N, 10.55 ; MS (ESI, ion polarity negative, $\mathrm{MeOH}$ ) : m/z: 908.0 $[\mathrm{M}-\mathrm{H}]^{-}$. 
Benzyl N-[(5S)-6-[2-(5-acetamido-2-methoxy-benzoyl)hydrazino]-6-oxo-5-[3-[[(3S,4S,5S)-

\section{3,4,5-tribenzyloxy-6-[3-[(imino-5-azanylidene)amino]propoxy]tetrahydropyran-2-}

yl]methoxy] propanoylamino]hexyl]carbamate (13). Same procedure as described for 12 from 11b (495 mg, $0.826 \mathrm{mmol})$ and $9(500 \mathrm{mg}, 0.826 \mathrm{mmol})$. The yellow crude product obtained was purified by puriflash column chromatography (SI-HP, $12 \mathrm{~g}, 22 \mathrm{bar}, 30 \mu \mathrm{m}$, flow rate: $20 \mathrm{~mL} / \mathrm{min}$ ) with eluent $\mathrm{CH}_{2} \mathrm{Cl}_{2} / \mathrm{CH}_{3} \mathrm{OH} 95 / 5$ to afford 13 as a white solid $(593 \mathrm{mg}, 68 \%, \alpha / \beta 50 / 50)$. $\mathrm{R}_{\mathrm{f}}=$ 0.15 et 0.25 (two diastereoisomers) $\left(\mathrm{CH}_{2} \mathrm{Cl}_{2} / \mathrm{CH}_{3} \mathrm{OH} 95 / 5\right) ;{ }^{1} \mathrm{H} \mathrm{NMR}\left(300 \mathrm{MHz}, \mathrm{CDCl}_{3}\right): \delta=$ $11.97(\mathrm{sl}, 1 \mathrm{H}, \mathrm{NH}) ; 11.32(\mathrm{sl}, 1 \mathrm{H}, \mathrm{NH}) ; 9.80(\mathrm{sl}, 1 \mathrm{H}, \mathrm{NH}) ; 8.58(\mathrm{~d}, J=7.7 \mathrm{~Hz}, 1 \mathrm{H}) ; 8.17$ (s, $1 \mathrm{H}) ; 7.32-7.26(\mathrm{~m}, 21 \mathrm{H}) ; 6.91(\mathrm{~m}, 1 \mathrm{H}) ; 5.41(\mathrm{~m}, 1 \mathrm{H}) ; 5.07-4.60\left(\mathrm{~m}, 9.50 \mathrm{H}, 9 \mathrm{H}+\mathrm{H}_{1 \beta}\right) ; 4.42(\mathrm{~d}$, $\left.J=7.8 \mathrm{~Hz}, 0.50 \mathrm{H}, \mathrm{H}_{1 \alpha}\right) ; 4.11-3.32(\mathrm{~m}, 15 \mathrm{H}) ; 2.99(\mathrm{~m}, 2 \mathrm{H}) ; 2.59(\mathrm{~s}, 2 \mathrm{H}) ; 2.21(\mathrm{~s}, 3 \mathrm{H}) ; 1.88(\mathrm{~m}$, $2 \mathrm{H}) ; 1.37(\mathrm{~m}, 6 \mathrm{H}) ;{ }^{13} \mathrm{C} \mathrm{NMR}\left(75 \mathrm{MHz}, \mathrm{CDCl}_{3}\right): \delta=174.2,173.3,169.2,165.5,156.3,153.3$, $138.5,138.0,137.8,136.7,133.8,128.5,128.3,128.0,127.8,125.0,122.1\left(\mathrm{C}_{30}\right), 117.7,111.9$, 103.6 $\left(\mathrm{C}_{1 \mathrm{H} \alpha}\right), 97.2\left(\mathrm{C}_{1 \mathrm{H} \beta}\right), 92.2,87.2,84.6,82.0,81.7,75.6,66.7\left(\mathrm{C}_{16}\right), 56.4,50.8,48.3,40.6$, 37.6, 34.1, 34.0, 33.9, 29.1, 24.0, 22.2, 20.48; MS (ESI, ion polarity positive, MeOH) : m/z: $1095.48[\mathrm{M}+\mathrm{Na}]^{+}$.

\section{$N$-[(1S)-1-[[(5-Acetamido-2-methoxy-benzoyl)amino]carbamoyl]-2-methyl-propyl]-3- [I(3S,4S,5S)-6-(3-aminopropoxy)-3,4,5-tribenzyloxy-tetrahydropyran-2-}

yl]methoxylpropanamide (14). To a stirred solution of 12 (174 mg, $0.19 \mathrm{mmol})$ in THF (2 mL) was added at room temperature $\mathrm{Ph}_{3} \mathrm{P}(100 \mathrm{mg}, 0.38 \mathrm{mmol})$. After 10 minutes, $\mathrm{H}_{2} \mathrm{O}(0.3 \mathrm{~mL})$ was added and the reaction was stirred at reflux at $40^{\circ} \mathrm{C}$ for $24 \mathrm{~h}$. The solvents were evaporated under reduced pressure and the oily residue obtained was purified by column chromatography on silica gel successively eluting with $\mathrm{CH}_{2} \mathrm{Cl}_{2} 100 \%$, then $\mathrm{CH}_{2} \mathrm{Cl}_{2} / \mathrm{CH}_{3} \mathrm{OH} 95 / 5, \mathrm{CH}_{2} \mathrm{Cl}_{2} / \mathrm{CH}_{3} \mathrm{OH} 90 / 10$ to eliminate the impurities and finally with $\mathrm{CH}_{2} \mathrm{Cl}_{2} / \mathrm{CH}_{3} \mathrm{OH} / \mathrm{NH}_{4} \mathrm{OH}$ (20\% aq. sol.) $88 / 9 / 3$ to 
afford $14(107 \mathrm{mg}, 63 \%, \alpha / \beta 40 / 60)$ as a white solid; $\mathrm{mp}=203-205{ }^{\circ} \mathrm{C} ; \mathrm{R}_{\mathrm{f}}=0.10$ $\left(\mathrm{CH}_{2} \mathrm{Cl}_{2} / \mathrm{CH}_{3} \mathrm{OH} / \mathrm{NH}_{4} \mathrm{OH}\right.$ (20\% aq. sol.) $88 / 9 / 3 ;{ }^{1} \mathrm{H} \mathrm{NMR}\left(300 \mathrm{MHz}, \mathrm{CDCl}_{3}\right): \delta=9.71$ (bs, $1 \mathrm{H}) ; 8.55(\mathrm{dd}, J=9.1,2.7 \mathrm{~Hz}, 1 \mathrm{H}) ; 8.25(\mathrm{~d}, J=2.7 \mathrm{~Hz}, 1 \mathrm{H}) ; 7.31-7.20(\mathrm{~m}, 16 \mathrm{H}) ; 6.92(\mathrm{~d}, J=$ 9.1, 1H); $5.25(\mathrm{~m}, 1 \mathrm{H}) ; 4.89-4.57\left(\mathrm{~m}, 6,40 \mathrm{H}, 6 \mathrm{H}+\mathrm{H}_{1 \beta}\right) ; 4.41\left(\mathrm{~d}, J=7.8 \mathrm{~Hz}, 0.60 \mathrm{H}, \mathrm{H}_{1 \alpha}\right) ; 3.94(\mathrm{~s}$, $3 \mathrm{H}) ; 3.91-3.36(\mathrm{~m}, 12 \mathrm{H}) ; 2.85(\mathrm{~m}, 2 \mathrm{H}) ; 2.58(\mathrm{~m}, 2 \mathrm{H}) ; 2.17(\mathrm{~s}, 3 \mathrm{H}) ; 2.08(\mathrm{~m}, 1 \mathrm{H}) ; 1.78(\mathrm{~m}, 2 \mathrm{H})$; $0.91(\mathrm{~m}, 6 \mathrm{H}) ;{ }^{13} \mathrm{C} \mathrm{NMR}\left(75 \mathrm{MHz}, \mathrm{CDCl}_{3}\right): \delta=171.3,169.0,165.4,158.4,153.1,138.6,138.5$, $138.0,133.9,128.4,128.3,128.0,127.8,127.6,127.5,124.8,122.5,117.8,111.8,103.6,84.6$, $82.3,77.9,75.5,75.0,74.8,70.2,67.7,56.4,56.0,38.9,37.5,33.2,33.0,24.3,19.0,18.3$; IR (neat) : 3465, $3418(\mathrm{HN}-\mathrm{H}) \mathrm{cm}^{-1}$; Anal. Calcd for $\mathrm{C}_{48} \mathrm{H}_{61} \mathrm{~N}_{5} \mathrm{O}_{11} \cdot\left(\mathrm{CH}_{3}\right)_{2} \mathrm{CO}: \mathrm{C}, 65.02 ; \mathrm{H}, 7.18 ; \mathrm{N}$, 7.44 Found C, 64.88; H, 7.55; N, 7.16 ; MS (ESI, ion polarity negative, $\mathrm{MeOH}$ ) : m/z: 882.7 $[\mathrm{M}-\mathrm{H}]^{-}$.

\section{Benzyl $N$-[(5S)-6-[2-(5-acetamido-2-methoxy-benzoyl)hydrazino]-5-[3-[[(3S,4S,5S)-6-(3-} aminopropoxy)-3,4,5-tribenzyloxy-tetrahydropyran-2-yl]methoxy]propanoylamino]-6-oxohexyl]carbamate (15)._Same procedure as described for 14 from 13 (497 mg, $0.463 \mathrm{mmol})$ to afford $15(247 \mathrm{mg}, 50 \%, \alpha / \beta 50 / 50)$ as a white solid. $\mathrm{R}_{\mathrm{f}}=0.1\left(\mathrm{CH}_{2} \mathrm{Cl}_{2} / \mathrm{CH}_{3} \mathrm{OH} / \mathrm{NH}_{4} \mathrm{OH}(20 \%\right.$ aq. sol.) $88 / 9 / 3) ;{ }^{1} \mathrm{H}$ NMR (300 MHz, $\left.\mathrm{CD}_{3} \mathrm{OD}\right): \delta=8.08(\mathrm{dd}, J=12.4,2.7 \mathrm{~Hz}, 1 \mathrm{H}) ; 7.70(\mathrm{~m}, 1 \mathrm{H})$; 7.34-7.22 (m, 20H); $6.98(\mathrm{~m}, 1 \mathrm{H}) ; 4.98(\mathrm{~s}, 2 \mathrm{H}) ; 4.97-4.53\left(\mathrm{~m}, 8.50 \mathrm{H}, 8 \mathrm{H}+\mathrm{H}_{1 \beta}\right) ; 4.41(\mathrm{~m}, 1 \mathrm{H})$, $4.37\left(\mathrm{~d}, J=7.7 \mathrm{~Hz}, 0.50 \mathrm{H}, \mathrm{H}_{1 \alpha}\right) ; 3.86(\mathrm{~s}, 3 \mathrm{H}), 3.80-3.21(\mathrm{~m}, 10 \mathrm{H}) 3.04(\mathrm{~m}, 2 \mathrm{H}) ; 2.85(\mathrm{~m}, 2 \mathrm{H})$ $2.48(\mathrm{~m}, 2 \mathrm{H}) ; 2.03(\mathrm{~m}, 3 \mathrm{H}) ; 1.87-1.67(\mathrm{~m}, 4 \mathrm{H}) ; 1.42(\mathrm{~m}, 4 \mathrm{H}) ;{ }^{13} \mathrm{C} \mathrm{NMR}\left(75 \mathrm{MHz}, \mathrm{CD}_{3} \mathrm{OD}\right): \delta$ $=173.9,171.5,171.3,164.6,164.2,158.8,155.5,140.0,139.9,139.6,139.5,138.3,133.5$, 129.4-128.6, 126.6, 126.3, 124.3, 124.2, 121.3, 121.2, 113.4, $104.7\left(\mathrm{C}_{1 \mathrm{H} \alpha}\right), 98.0\left(\mathrm{C}_{1 \mathrm{H \beta}}\right), 85.6$, $83.4,83.0,81.4,79.1,78.9,76.4,76.0,75.9,75.6,75.3,74.0,71.7,70.7,68.6,68.5,68.3,67.5$, $67.3,56.9,53.8,53.7,49.9,41.5,39.8,39.3,37.5,37.3,33.0,32.9,30.9,30.4,24.0,23.9,23.7$; 
HRMS (TOF, ESI, ion polarity positive, $\mathrm{H}_{2} \mathrm{O} / \mathrm{MeOH}$ ): $\mathrm{m} / \mathrm{z}[\mathrm{M}+\mathrm{H}]^{+}$, calcd for $\mathrm{C}_{57} \mathrm{H}_{71} \mathrm{~N}_{6} \mathrm{O}_{13}$ 1047.5079; found 1047.5063.

tert-Butyl $\quad N$-[(1S)-1-[3-[6-[[3-[[(1S)-1-[[(5-acetamido-2-methoxy-benzoyl)amino] carbamoyl]-2-methyl-propyl]amino]-3-oxo-propoxy]methyl]-3,4,5-tribenzyloxytetrahydropyran-2-yl]oxypropylcarbamoyl]-2-methyl-propyl]carbamate (16). To a stirred solution of $N$-Boc-Val-OH (132 mg, $0.60 \mathrm{mmol})$ in dry DMF $(2 \mathrm{~mL})$ and cooled at $0{ }^{\circ} \mathrm{C}$, under azote atmosphere, were successively added DMTMM (98.4 mg, $0.30 \mathrm{mmol})$ and NMM (100 $\mu \mathrm{L}$, $0.91 \mathrm{mmol})$. The reaction mixture was stirred at $0{ }^{\circ} \mathrm{C}$ for $1 \mathrm{~h}$. Then $\mathbf{1 4}(270 \mathrm{mg}, 0.30 \mathrm{mmol})$ in dry DMF $(2 \mathrm{~mL})$ was added to the reaction mixture. The ice bath was removed after 30 minutes and the orange reaction mixture was stirred at room temperature overnight. The solvent was evaporated under reduced pressure and the oily residue obtained was taken up with EtOAc (50 $\mathrm{mL}$ ). The organic layer was successively washed with distilled water, $10 \%$ citric acid aqueous solution, $10 \% \mathrm{~K}_{2} \mathrm{CO}_{3}$ aqueous solution, and brine, dried over anhydrous $\mathrm{Na}_{2} \mathrm{SO}_{4}$, filtered and concentrated under reduced pressure. The oily crude product was purified by puriflash column chromatography (SI-HP, $12 \mathrm{~g}, 22$ bars, $30 \mu \mathrm{m}$, flow rate: $20 \mathrm{~mL} / \mathrm{min}$ ) with eluent $\mathrm{CH}_{2} \mathrm{Cl}_{2} / \mathrm{CH}_{3} \mathrm{OH} 95 / 5$ to afford $16(260 \mathrm{mg}, 79 \%, \alpha / \beta 40 / 60)$ as a white solid. $\mathrm{R}_{\mathrm{f}}=0.35$ $\left(\mathrm{CH}_{2} \mathrm{Cl}_{2} / \mathrm{CH}_{3} \mathrm{OH} 95 / 5\right) ;{ }^{1} \mathrm{H}$ NMR $\left(300 \mathrm{MHz}, \mathrm{CD}_{3} \mathrm{OD}\right): \delta=8.04(\mathrm{~s}, 1 \mathrm{H}) ; 7.80(\mathrm{~d}, J=8.8,2.7 \mathrm{~Hz}$, $1 \mathrm{H}) ; 7.34-7.25(\mathrm{~m}, 15 \mathrm{H}) ; 7.10(\mathrm{~d}, J=8.8 \mathrm{~Hz}, 1 \mathrm{H}) ; 4.93-4.61\left(\mathrm{~m}, 6.40 \mathrm{H}, 6 \mathrm{H}+\mathrm{H}_{1 \beta}\right) ; 4.44(\mathrm{~d}, J=$ $\left.7.8 \mathrm{~Hz}, 0.60 \mathrm{H}, \mathrm{H}_{1 \alpha}\right) ; 4.34(\mathrm{~d}, J=6.8 \mathrm{~Hz}, 1 \mathrm{H}) ; 3.94(\mathrm{~s}, 3 \mathrm{H}) ; 3.81-3.29(\mathrm{~m}, 13 \mathrm{H}) ; 2.61-2.46(\mathrm{~m}$, 2H); 2.14-2.09 (m, 4H); 199-1.79 (m, 3H); $1.45(\mathrm{~s}, 9 \mathrm{H}) ; 1.04(\mathrm{dd}, J=11.2,6.7 \mathrm{~Hz}, 6 \mathrm{H}) ; 0.93(\mathrm{~m}$, $6 \mathrm{H}) ;{ }^{13} \mathrm{C} \mathrm{NMR}\left(75 \mathrm{MHz}, \mathrm{CD}_{3} \mathrm{OD}\right): \delta=174.4,174.2,171.5,171.4,157.9,155.6,140.3,139.9$, $139.6,133.5,129.5,129.3,129.0,128.9,128.6,128.5,126.7,124.3,121.2,113.4,104.8\left(\mathrm{C}_{1 \mathrm{H} \alpha}\right)$, $98.1\left(\mathrm{C}_{1 \mathrm{H} \beta}\right), 83.0,81.4,78.9,76.4,76.0,75.9,75.8,73.9,71.6,70.5,68.6,67.4,61.8,58.9,57.0$, 
38.0, 37.5, 32.0, 31.6, 30.3, 28.7, 23.6, 19.8, 18.9, 18.6; MS (ESI, ion polarity negative, MeOH) : $\mathrm{m} / \mathrm{z}: 1081.9[\mathrm{M}-\mathrm{H}]^{-}$.

tert-Butyl N-[(1S)-2-[[(1S)-1-[3-[(3S,4S,5R)-6-[[3-[[(1S)-1-[[(5-acetamido-2-methoxybenzoyl)amino]carbamoyl]-5-(benzyloxycarbonylamino)pentyl]amino]-3-oxopropoxy]methyl]-3,4,5-tribenzyloxy-tetrahydropyran-2-yl]oxypropylcarbamoyl]-2-methylpropyl]amino]-1-methyl-2-oxo-ethyl]carbamate (17). Same procedure as described for 16 from 15 (245 mg, $0.234 \mathrm{mmol})$ to afford 17 as a white solid $(200 \mathrm{mg}, 68 \%, \alpha / \beta 50 / 50)$. $\mathrm{R}_{\mathrm{f}}=0.35$ et 0.40 (two diastereoisomers) $\left(\mathrm{CH}_{2} \mathrm{Cl}_{2} / \mathrm{CH}_{3} \mathrm{OH}: 95 / 5\right) ;{ }^{1} \mathrm{H} \mathrm{NMR}\left(300 \mathrm{MHz}, \mathrm{CD}_{3} \mathrm{OD}\right): \delta=8.06$ $(\mathrm{s}, 1 \mathrm{H}) ; 7.83(\mathrm{~m}, 1 \mathrm{H}) ; 7.29-7.23(\mathrm{~m}, 20 \mathrm{H}) ; 7.04(\mathrm{dd}, J=9.0,3.6 \mathrm{~Hz}, 1 \mathrm{H}) ; 5.03(\mathrm{~m}, 2 \mathrm{H}) ; 4.91-$ $4.57\left(\mathrm{~m}, 6.50 \mathrm{H}, 6 \mathrm{H}+\mathrm{H}_{1 \beta}\right) ; 4.51(\mathrm{~m}, 1 \mathrm{H}) ; 4.40\left(\mathrm{~d}, J=7.8 \mathrm{~Hz}, 0.50 \mathrm{H}, \mathrm{H}_{1 \alpha}\right) ; 3.88(\mathrm{~s}, 3 \mathrm{H}) ; 3.84-$ $3.48(\mathrm{~m}, 10 \mathrm{H}) ; 3.43-3.28(\mathrm{~m}, 3 \mathrm{H}) ; 3.08(\mathrm{~m}, 2 \mathrm{H}) ; 2.53(\mathrm{~m}, 2 \mathrm{H}) ; 2.08(\mathrm{~m}, 3 \mathrm{H}) ; 2.00-1.78(\mathrm{~m}$, $5 \mathrm{H}) ; 1.49(\mathrm{~m}, 4 \mathrm{H}) ; 1.42(\mathrm{~s}, 9 \mathrm{H}) ; 0.90(\mathrm{~m}, 6 \mathrm{H}) ;{ }^{13} \mathrm{C} \mathrm{NMR}\left(75 \mathrm{MHz}, \mathrm{CD}_{3} \mathrm{OD}\right): \delta=174.3,174.1$, $174.0,172.1,171.4,165.3,158.8,157.8,155.5,140-139.6,138.4,133.6,129.4-128.5,126.8$, 124.3, 120.9, 113.4, $104.8\left(\mathrm{C}_{1 \mathrm{H} \alpha}\right), 98.1\left(\mathrm{C}_{1 \mathrm{H} \beta}\right), 85.7,83.5,83.0,81.6,80.5,79.1,76.5,76.0,75.7$, $73.9,71.6,70.8,70.6,68.5,67.3,61.7,61.6,57.0,53.3,41.5,37.6,32.8,32.7,32.1,30.7,30.4$, 28.7, 24.0, 23.9, 23.7, 19.8, 18.6 ; MS (ESI, ion polarity positive, $\mathrm{MeOH)} \mathrm{:} \mathrm{m/z:} 1268.61$ $[\mathrm{M}+\mathrm{Na}]^{+}$. HRMS (TOF, ESI, ion polarity positive, $\left.\mathrm{H}_{2} \mathrm{O} / \mathrm{MeOH}\right): \mathrm{m} / \mathrm{z}[\mathrm{M}+\mathrm{Na}]^{+}$, calcd for $\mathrm{C}_{67} \mathrm{H}_{87} \mathrm{~N}_{7} \mathrm{O}_{16} \mathrm{Na}$ 1268.6102; found 1268.6093.

tert-Butyl $\quad N-[(1 S)-2-[[(1 S)-1-[3-[6-[[3-[[(1 S)-1-[[(5-a c e t a m i d o-2-m e t h o x y-$ benzoyl)amino]carbamoyl]-2-methyl-propyl]amino]-3-oxo-propoxy]methyl]-3,4,5tribenzyloxy-tetrahydropyran-2-yl]oxypropylcarbamoyl]-2-methyl-propyl]amino]-1methyl-2-oxo-ethyl]carbamate (18). To a stirred solution of 16 (270 mg, $0.25 \mathrm{mmol})$ in dry $\mathrm{CH}_{2} \mathrm{Cl}_{2}(2 \mathrm{~mL})$, cooled to $0{ }^{\circ} \mathrm{C}$ was carefully added TFA $(1 \mathrm{~mL})$. After 30 minutes the ice bath 
was removed and the reaction mixture was stirred at room temperature for $3 \mathrm{~h}$. The solvent was evaporated at reduced pressure and the viscous oily residue was taken up with toluene and again evaporated. The oily residue obtained was triturated in $\mathrm{Et}_{2} \mathrm{O}$ to yield the TFA salt of the free amine 16a (301 mg, quantitative, $\alpha / \beta 50 / 50)$ as a white solid. $\mathrm{R}_{\mathrm{f}}=0\left(\mathrm{CH}_{2} \mathrm{Cl}_{2} / \mathrm{CH}_{3} \mathrm{OH}: 95 / 5\right) ;{ }^{1} \mathrm{H}$ NMR $\left(300 \mathrm{MHz}, \mathrm{CD}_{3} \mathrm{OD}\right): \delta=8.06(\mathrm{~m}, 1 \mathrm{H}) ; 7.72(\mathrm{dd}, J=8.7,2.8 \mathrm{~Hz}, 1 \mathrm{H}) ; 7.28-7.21(\mathrm{~m}$, $15 \mathrm{H}) ; 7.03(\mathrm{dd}, J=9.0,2.3 \mathrm{~Hz}, 1 \mathrm{H}) ; 4.86-4.56\left(\mathrm{~m}, 6.50 \mathrm{H}, 6 \mathrm{H}+\mathrm{H}_{1 \beta}\right) ; 4.44(\mathrm{~d}, J=7.8 \mathrm{~Hz}, 0.50 \mathrm{H}$, $\left.\mathrm{H}_{1 \alpha}\right) ; 4.37(\mathrm{~d}, J=6.9,1 \mathrm{H}) ; 3.91(\mathrm{~s}, 3 \mathrm{H}) ; 3.80-3.34(\mathrm{~m}, 13 \mathrm{H}) ; 2.50(\mathrm{~m}, 2 \mathrm{H}) ; 2.12(\mathrm{~m}, 2 \mathrm{H}) ; 2.06(\mathrm{~s}$, $3 \mathrm{H}) ; 1.80(\mathrm{~m}, 2 \mathrm{H}) ; 1.02-0.95(\mathrm{~m}, 12 \mathrm{H}) ;{ }^{13} \mathrm{C} \mathrm{NMR}\left(75 \mathrm{MHz}, \mathrm{CD}_{3} \mathrm{OD}\right): \delta=174.2,171.4,171.4$, $169.3,165.4,155.5,140.1,140.0,139.9,139.7,139.5,133.5,129.4,129.3,129.2,129.0,128.9$, 128.7, 128.5, 126.8, 124.3, 121.0, 113.4, $104.8\left(\mathrm{C}_{1 \mathrm{H \alpha}}\right), 98.1\left(\mathrm{C}_{1 \mathrm{H} \beta}\right), 85.7,83.0,81.4,80.6,78.9$, $76.3,76.1,75.7,75.5,71.6,73.9,71.6,70.6,68.2,67.0,59.9,58.8,56.9,38.0,37.8,37.4,32.0$, 31.9, 31.4, 30.3, 23.6, 19.7, 18.9, 18.8, 18.1, 17.9 ; MS (ESI, ion polarity negative, $\mathrm{MeOH}): \mathrm{m} / \mathrm{z}$ : $983.53[\mathrm{M}+\mathrm{H}]^{+}$.

Same procedure as described for 12 from $N$-Boc-L-Ala-OH (102.6 mg, 0.55 mmol, 2 eq.) and $16 \mathbf{a}(300 \mathrm{mg}, 0.273 \mathrm{mmol})$ to afford 18 as a white solid $(210 \mathrm{mg}, 68 \%, \alpha / \beta 50 / 50) . \mathrm{R}_{\mathrm{f}}=0.20$ $\left(\mathrm{CH}_{2} \mathrm{Cl}_{2} / \mathrm{CH}_{3} \mathrm{OH}: 95 / 5\right) ;{ }^{1} \mathrm{H}$ NMR $\left(300 \mathrm{MHz}, \mathrm{CD}_{3} \mathrm{OD}\right): \delta=8.04(\mathrm{~d}, J=2.8 \mathrm{~Hz}, 1 \mathrm{H}) ; 7.85(\mathrm{~m}$, $1 \mathrm{H}) ; 7.40-7.19(\mathrm{~m}, 15 \mathrm{H}) ; 7.11(\mathrm{~m}, 1 \mathrm{H}) ; 5.00-4.69\left(\mathrm{~m}, 6.50 \mathrm{H}, 6 \mathrm{H}+\mathrm{H}_{1 \beta}\right) ; 4.43(\mathrm{~d}, J=7.9 \mathrm{~Hz}$, $\left.0.50 \mathrm{H}, \mathrm{H}_{1 \alpha}\right) ; 4.38(\mathrm{~d}, J=6.9 \mathrm{~Hz}, 1 \mathrm{H}) ; 4.22-4.06(\mathrm{~m}, 2 \mathrm{H}) ; 3.95(\mathrm{~s}, 3 \mathrm{H}) ; 3.84-3.28(\mathrm{~m}, 12 \mathrm{H}) ; 2.67-$ $2.44(\mathrm{~m}, 2 \mathrm{H}) ; 2.25-2.11(\mathrm{~m}, 5 \mathrm{H}) ; 1.83(\mathrm{~m}, 2 \mathrm{H}) ; 1.44(\mathrm{~s}, 9 \mathrm{H}) ; 1.30(\mathrm{~m}, 3 \mathrm{H}) ; 1.05(\mathrm{~m}, 6 \mathrm{H}) ; 0.93$ $(\mathrm{m}, J=6.5 \mathrm{~Hz}, 6 \mathrm{H}) ;{ }^{13} \mathrm{C} \mathrm{NMR}\left(75 \mathrm{MHz}, \mathrm{CDCl}_{3}\right): \delta=172.8,172.7,171.1,171.0,169.0,165.3$, $158.5,153.1,138.8,138.5,138.4,138.1,133.7,128.4,128.3,128.2,127.9,127.8,127.7,127.4$, 124.9, 122.5, 117.8, 111.8, $103.6\left(\mathrm{C}_{1 \mathrm{H} \alpha}\right), 97.1\left(\mathrm{C}_{1 \mathrm{H} \beta}\right), 84.5,82.1,82.0,80.1,80.0,77.7,75.5$, $75.4,74.9,74.7,74.6,73.2,70.2,70.0,69.9,67.9,67.6,67.4,66.7,58.5,56.4,55.9,50.3,37.4$, 
37.3, 33.0, 31.0, 30.9, 29.2, 28.2, 24.2, 19.3, 18.9, 18.2, 17.7 ; HRMS (TOF, ESI, ion polarity positive, $\left.\mathrm{H}_{2} \mathrm{O} / \mathrm{MeOH}\right): \mathrm{m} / \mathrm{z}[\mathrm{M}+\mathrm{Na}]^{+}$, calcd for $\mathrm{C}_{61} \mathrm{H}_{83} \mathrm{~N}_{7} \mathrm{O}_{15} \mathrm{Na} 1176.5839$; found 1176.5827 .

tert-Butyl N-[(1S)-2-[[(1S)-1-[3-[(3S,4S,5R)-6-[[3-[[(1S)-1-[[(5-acetamido-2-methoxybenzoyl)amino]carbamoyl]-5-(benzyloxycarbonylamino)pentyl]amino]-3-oxopropoxy]methyl]-3,4,5-tribenzyloxy-tetrahydropyran-2-yl]oxypropylcarbamoyl]-2-methylpropyl]amino]-1-methyl-2-oxo-ethyl] carbamate (19).

Same procedure as described for 18 from $17(200 \mathrm{mg}, 0.16 \mathrm{mmol})$ to afford the TFA salt of the free amine 17a as a white solid (207 mg, quantitative, $\alpha / \beta 50 / 50) . \mathrm{R}_{\mathrm{f}}=0\left(\mathrm{CH}_{2} \mathrm{Cl}_{2} / \mathrm{CH}_{3} \mathrm{OH}: 95 / 5\right)$ ; ${ }^{1} \mathrm{H}$ NMR $\left(300 \mathrm{MHz}, \mathrm{CD}_{3} \mathrm{OD}\right): \delta=8.14(\mathrm{~m}, 1 \mathrm{H}) ; 7.74(\mathrm{~d}, J=9.0 \mathrm{~Hz}, 1 \mathrm{H}) ; 7.35-7.23(\mathrm{~m}$, $20 \mathrm{H}) ; 7.12(\mathrm{~d}, J=9.0 \mathrm{~Hz}, 1 \mathrm{H}) ; 5.03(\mathrm{~s}, 2 \mathrm{H}) ; 4.88-4.48\left(\mathrm{~m}, 7.50 \mathrm{H}, 7 \mathrm{H}+\mathrm{H}_{1 \beta}\right) ; 4.41(\mathrm{~d}, J=7.9$ $\left.\mathrm{Hz}, 0.50 \mathrm{H}, \mathrm{H}_{1 \alpha}\right) ; 3.90(\mathrm{~s}, 3 \mathrm{H}) ; 3.89-3.20(\mathrm{~m}, 13 \mathrm{H}) ; 3.07(\mathrm{~m}, 2 \mathrm{H}) ; 2.55(\mathrm{~m}, 2 \mathrm{H}) ; 2.13(\mathrm{~m}, 1 \mathrm{H})$, $2.08(\mathrm{~m}, 3 \mathrm{H}) ; 1.93-1.75(\mathrm{~m}, 4 \mathrm{H}) ; 1.51(\mathrm{~m}, 4 \mathrm{H}) ; 1.02(\mathrm{~m}, 6 \mathrm{H}) ;{ }^{13} \mathrm{C} \mathrm{NMR}\left(75 \mathrm{MHz}, \mathrm{CD}_{3} \mathrm{OD}\right): \delta$ $=174.2,172.2,171.5,169.4,165.5,158.8,155.6,140.1,139.9,139.7,138.4,133.5,129.4-128.6$, 126.8, 124.3, 120.9, 113.5, $104.8\left(\mathrm{C}_{1 \mathrm{H} \alpha}\right), 98.0\left(\mathrm{C}_{1 \mathrm{H} \beta}\right), 85.7,83.4,83.0,81.6,79.0,76.5,76.1$, $75.9,75.6,73.9,71.6,70.7,68.5,68.3,67.3,67.0,59.9,57.0,53.4,41.5,37.8,37.5,32.7,31.4$, 30.4, 24.0, 23.7, 18.9, 18.1, 18.0; HRMS (TOF, ESI, ion polarity positive, $\mathrm{H}_{2} \mathrm{O} / \mathrm{MeOH}$ ): $\mathrm{m} / \mathrm{z}$ $[\mathrm{M}+\mathrm{H}]^{+}$, calcd for $\mathrm{C}_{62} \mathrm{H}_{80} \mathrm{~N}_{7} \mathrm{O}_{14} 1146.5763$; found 1146.5752 .

Same procedure as described for 12 from $N$-Boc-L-Ala-OH $(59.5 \mathrm{mg}, 0.32 \mathrm{mmol})$ and $\mathbf{1 7 a}$ (200 $\mathrm{mg}, 0.16 \mathrm{mmol})$ to afford 19 as a white solid $(152 \mathrm{mg}, 73 \%, \alpha / \beta 50 / 50) . \mathrm{R}_{\mathrm{f}}=0.30$ $\left(\mathrm{CH}_{2} \mathrm{Cl}_{2} / \mathrm{CH}_{3} \mathrm{OH}: 95 / 5\right) ;{ }^{1} \mathrm{H} \mathrm{NMR}\left(300 \mathrm{MHz}, \mathrm{CD}_{3} \mathrm{OD}\right): \delta=8.05(\mathrm{~m}, 1 \mathrm{H}) ; 7.82(\mathrm{~s}, 1 \mathrm{H}) ; 7.38-$ $7.23(\mathrm{~m}, 20 \mathrm{H}) ; 7.11(\mathrm{~m}, 2 \mathrm{H}) ; 5.05(\mathrm{~m}, 2 \mathrm{H}) ; 4.91-4.59\left(\mathrm{~m}, 6.50 \mathrm{H}, 6 \mathrm{H}+\mathrm{H}_{1 \beta}\right) ; 4.49(\mathrm{~m}, 1 \mathrm{H}) ; 4.40$ $\left(\mathrm{d}, J=7.8 \mathrm{~Hz}, 0.50 \mathrm{H}, \mathrm{H}_{1 \alpha}\right) ; 4.10(\mathrm{~m}, 2 \mathrm{H}) ; 3.92(\mathrm{~s}, 3 \mathrm{H}) ; 3.89(\mathrm{~m}, 1 \mathrm{H}) ; 3.76-3.31(\mathrm{~m}, 11 \mathrm{H}) ; 3.09$ $(\mathrm{s}, 2 \mathrm{H}) ; 2.54(\mathrm{~s}, 2 \mathrm{H}) ; 2.09(\mathrm{~m}, 3 \mathrm{H}) ; 2.02(\mathrm{~m}, 1 \mathrm{H}) ; 1.91-1.78(\mathrm{~m}, 4 \mathrm{H},) ; 1.49(\mathrm{~m}, 4 \mathrm{H}) ; 1.41(\mathrm{~s}$, 
$9 \mathrm{H}) ; 1.28(\mathrm{~s}, 3 \mathrm{H}) ; 0.91(\mathrm{~m}, 6 \mathrm{H}) ;{ }^{13} \mathrm{C} \mathrm{NMR}\left(75 \mathrm{MHz}, \mathrm{CD}_{3} \mathrm{OD}\right): \delta=175.8,174.2,172.2,172.0$, $171.5,169.4,165.5,164.3,158.7,155.7,140.1,138.6,133.5,129.4,129.3,129.2,129.0,128.9$, 128.5, 126.9, 124.3, 120.9, 113.5, $104.8\left(\mathrm{C}_{1 \mathrm{H} \alpha}\right), 98.0\left(\mathrm{C}_{1 \mathrm{H} \beta}\right), 83.4,81.6,80.8,79.1,76.5,76.1$, $75.9,73.9,71.6,70.7,68.5,67.3,67.2,60.0,57.0,53.4,51.7,44.6,41.5,37.9,37.5,32.6,32.1$, 30.6, 30.4, 28.7, 23.9, 23.7, 19.1, 18.4, 18.0, 17.9 ; MS (ESI, ion polarity positive, MeOH) : m/z: 1339,65 [M+Na] $]^{+}$. HRMS (TOF, ESI, ion polarity positive, $\mathrm{H}_{2} \mathrm{O} / \mathrm{MeOH}$ ): $\mathrm{m} / \mathrm{z}[\mathrm{M}+\mathrm{H}]^{+}$, calcd for $\mathrm{C}_{70} \mathrm{H}_{92} \mathrm{~N}_{8} \mathrm{O}_{17} \mathrm{Na}$ 1339.6478; found 1339.6483. HPLC purity: TR $(\alpha, \beta)=23.54,23.87$ min., 93.5 $\%$.

tert-Butyl N-[(1S)-2-[[(1S)-1-[3-[(3S,4S,5S)-6-[[3-[[(1S)-1-[[(5-acetamido-2-methoxybenzoyl)amino]carbamoyl]-2-methyl-propyl]amino]-3-oxo-propoxy]methyl]-3,4,5trihydroxy-tetrahydropyran-2-yl]oxypropylcarbamoyl]-2-methyl-propyl]amino]-1-methyl2-oxo-ethyl]carbamate (20). To a stirred solution of 18 (105 mg, $0.091 \mathrm{mmol})$ in $\mathrm{CH}_{3} \mathrm{OH}(3$ $\mathrm{mL}$ ) was added $\mathrm{Pd} / \mathrm{C}$ (25 $\mathrm{mg}, 25 \%$ mass). The reaction flask was purged three times with hydrogen, and stirring was maintained under hydrogen atmosphere at room temperature for 2 days. Upon completion of the reaction monitored by TLC, the solution was filtered through a pad of Celite which was washed several times with $\mathrm{CH}_{3} \mathrm{OH}$. Then, the filtrate was concentrated under reduced pressure to provide $20(70.7 \mathrm{mg}, 88 \%, \alpha / \beta 50 / 50)$ as a white solid. $\mathrm{R}_{\mathrm{f}}=0\left(\mathrm{CH}_{2} \mathrm{Cl}_{2} /\right.$ $\left.\mathrm{CH}_{3} \mathrm{OH}: 95 / 5\right) ;{ }^{1} \mathrm{H} \mathrm{NMR}\left(300 \mathrm{MHz}, \mathrm{CD}_{3} \mathrm{OD}\right): \delta=7.97(\mathrm{~s}, 1 \mathrm{H}) ; 7.77(\mathrm{dd}, J=9.0,2.2 \mathrm{~Hz}, 1 \mathrm{H})$; $7.07(\mathrm{~d}, J=9.0 \mathrm{~Hz}, 1 \mathrm{H}) ; 4.71\left(\mathrm{~d}, J=3.6 \mathrm{~Hz}, 0.50 \mathrm{H}, \mathrm{H}_{1 \beta}\right) ; 4.35(\mathrm{~d}, J=6.9 \mathrm{~Hz}, 1 \mathrm{H}) ; 4.21(\mathrm{~d}, J=$ $\left.7.8 \mathrm{~Hz}, 0.50 \mathrm{H}, \mathrm{H}_{1 \alpha}\right) ; 4.08(\mathrm{~m}, 1 \mathrm{H}) ; 3.93(\mathrm{~s}, 3 \mathrm{H}) ; 3.75-3.24(\mathrm{~m}, 12 \mathrm{H}) ; 2.52(\mathrm{~m}, 2 \mathrm{H}) ; 2.13(\mathrm{~m}$, $1 \mathrm{H}) ; 2.08(\mathrm{~s}, 3 \mathrm{H}) ; 2.00(\mathrm{~m}, 1 \mathrm{H}) ; 1.75(\mathrm{~m}, \mathrm{H}) ; 1.39(\mathrm{~s}, 9 \mathrm{H}) ; 1.26(\mathrm{~d}, J=7.2 \mathrm{~Hz}, 3 \mathrm{H}) ; 1.01(\mathrm{~m}$, $6 \mathrm{H}) ; 0.89(\mathrm{~d}, J=6.7 \mathrm{~Hz}, 6 \mathrm{H}) ;{ }^{13} \mathrm{C} \mathrm{NMR}\left(75 \mathrm{MHz}, \mathrm{CD}_{3} \mathrm{OD}\right): \delta=175.6,174.2,173.2,171.7$, $171.6,165.5,155.6,155.6,133.4,126.9,124.3,121.1,113.4,104.3\left(\mathrm{C}_{1 \mathrm{H} \alpha}\right), 100.2\left(\mathrm{C}_{1 \mathrm{H} \beta}\right), 80.7$, 
$77.9,76.7,75.0,73.4,72.5,71.6,71.5,71.3,71.2,68.7,68.6,67.2,60.1,58.8,58.7,57.0,51.7$ 37.9, 37.4, 32.0, 32,2, 32.0, 30.0, 28.7, 23.6, 19.7, 18.8, 18.7, 17.9 ; HRMS (TOF, ESI, ion polarity positive, $\left.\mathrm{H}_{2} \mathrm{O} / \mathrm{MeOH}\right): \mathrm{m} / \mathrm{z}[\mathrm{M}+\mathrm{Na}]^{+}$, calcd for $\mathrm{C}_{40} \mathrm{H}_{65} \mathrm{~N}_{7} \mathrm{O}_{15} \mathrm{Na}$ 906.4436; found 906.4421. HPLC purity: TR $(\alpha, \beta)=17.56$ min., $97.1 \%$.

tert-Butyl N-[(1S)-2-[[(1S)-1-[3-[(3S,4S,5S)-6-[[3-[[(1S)-1-[[(5-acetamido-2-methoxybenzoyl)amino]carbamoyl]-5-amino-pentyl]amino]-3-oxo-propoxy]methyl]-3,4,5trihydroxy-tetrahydropyran-2-yl]oxypropylcarbamoyl]-2-methyl-propyl]amino]-1-methyl2-oxo-ethyl]carbamate (21). Same procedure as described for 20 from 19 (111 mg, 0.083 mmol) in $\mathrm{CH}_{3} \mathrm{OH}(3 \mathrm{~mL})$ except that $\mathrm{CH}_{3} \mathrm{CO}_{2} \mathrm{H}$ was added $(1 \mathrm{~mL})$ to provide 21 (61.6 $\mathrm{mg}, 75 \%$, $\alpha / \beta 50 / 50)$ as a white solid. $\mathrm{R}_{\mathrm{f}}=0\left(\mathrm{CH}_{2} \mathrm{Cl}_{2} / \mathrm{CH}_{3} \mathrm{OH}: 95 / 5\right) ;{ }^{1} \mathrm{H} \mathrm{NMR}\left(300 \mathrm{MHz}, \mathrm{CD}_{3} \mathrm{OD}\right): \delta=$ $8.12(\mathrm{~s}, 1 \mathrm{H}) ; 7.73(\mathrm{~s}, 1 \mathrm{H}) ; 7.13(\mathrm{~d}, J=8.6 \mathrm{~Hz}, 1 \mathrm{H}) ; 4.76\left(\mathrm{~d}, J=3.6 \mathrm{~Hz}, 0.50 \mathrm{H}, \mathrm{H}_{1 \beta}\right) ; 4.54(\mathrm{~m}$, $1 \mathrm{H}), 4.26\left(\mathrm{~d}, J=7.6 \mathrm{~Hz}, 0.50 \mathrm{H}, \mathrm{H}_{1 \alpha}\right) ; 4.13(\mathrm{~m}, 2 \mathrm{H}) ; 3.97(\mathrm{~s}, 3 \mathrm{H}) ; 3.89-3.57(\mathrm{~m}, 6 \mathrm{H}) ; 3.34-$ $3.26(\mathrm{~m}, 5 \mathrm{H}) ; 3.17(\mathrm{~m}, 1 \mathrm{H}) ; 2.97$ (m, 2H); $2.55(\mathrm{~m}, 2 \mathrm{H}) ; 2.12(\mathrm{~s}, 3 \mathrm{H}) ; 2.04(\mathrm{~m}, 1 \mathrm{H}) ; 1.96(\mathrm{~s}, 8 \mathrm{H}$, $\left.2 \mathrm{H}+\mathrm{CH}_{3} \mathrm{CO}_{2} \mathrm{H}\right) ; 1.78(\mathrm{~m}, 4 \mathrm{H}) ; 1.56(\mathrm{~m}, 2 \mathrm{H}) ; 1.43(\mathrm{~s}, 9 \mathrm{H}) ; 1.29(\mathrm{~m}, 3 \mathrm{H}) ; 0.93(\mathrm{~d}, J=6.6 \mathrm{~Hz}$ $6 \mathrm{H}) ;{ }^{13} \mathrm{C}$ NMR $\left(75 \mathrm{MHz}, \mathrm{CD}_{3} \mathrm{OD}\right): \delta=177.3,175.8,174.4,173.3,171.6,157.8,155.7,133.5$, 130.5, 126.9, 124.4, 121.0, 113.5, $104.4\left(\mathrm{C}_{1 \mathrm{H} \alpha}\right), 100.3\left(\mathrm{C}_{1 \mathrm{H} \beta}\right), 8.7,77.9,76.7,75.1,73.5,72.6$, $71.6,71.5,71.1,68.6,67.2,60.1,57.0,53.0,51.7,45.8,40.5,37.9,37.7,37.4,32.5,32.2,30.2$, 28.7, 28.1, 26.9, 23.7, 22.1, 19.7, 19.3, 18.6, 17.9; HRMS (TOF, ESI, ion polarity positive, $\mathrm{H}_{2} \mathrm{O}$ / $\mathrm{MeOH}): \mathrm{m} / \mathrm{z}[\mathrm{M}+\mathrm{H}]^{+}$, calcd for $\mathrm{C}_{41} \mathrm{H}_{69} \mathrm{~N}_{8} \mathrm{O}_{15}$ 913.4882; found 913.4883, $\mathrm{m} / \mathrm{z}[\mathrm{M}+\mathrm{Na}]^{+}$, calcd for $\mathrm{C}_{41} \mathrm{H}_{68} \mathrm{~N}_{8} \mathrm{O}_{15} \mathrm{Na} 935.4702$, found 935.4708 ; HPLC purity: TR $(\alpha, \beta)=12.8,13.1 \mathrm{~min} ., 88.9 \%$.

$(2 S)-N-[3-[(3 S, 4 S, 5 S)-6-[[3-[[(1 S)-1-[[(5-A c e t a m i d o-2-m e t h o x y-$ benzoyl)amino]carbamoyl]-2-methyl-propyl]amino]-3-oxo-propoxy]methyl]-3,4,5tribenzyloxy-tetrahydropyran-2-yl]oxypropyl]-2-[[(2S)-2-aminopropanoyl]amino]-3- 
methyl-butanamide (22). Same procedure as described for $\mathbf{1 6 a}$ from 18 (38 $\mathrm{mg}, 0.033 \mathrm{mmol})$ in dry $\mathrm{CH}_{2} \mathrm{Cl}_{2}(270 \mu \mathrm{L})$ to yield 22 as a white solid (40 mg, quantitative, $\left.\alpha / \beta 50 / 50\right) . \mathrm{R}_{\mathrm{f}}=0$ $\left(\mathrm{CH}_{2} \mathrm{Cl}_{2} / \mathrm{CH}_{3} \mathrm{OH}: 95 / 5\right) ;{ }^{1} \mathrm{H}$ NMR $\left(300 \mathrm{MHz}, \mathrm{CD}_{3} \mathrm{OD}\right): \delta=8.12(\mathrm{~m}, 1 \mathrm{H}) ; 7.77(\mathrm{~d}, J=8.9 \mathrm{~Hz}$, $1 \mathrm{H}) ; 7.35-7.26(\mathrm{~m}, 15 \mathrm{H}) ; 7.10(\mathrm{~d}, J=8.9 \mathrm{~Hz}, 1 \mathrm{H}) ; 5.07-4.61\left(\mathrm{~m}, 6.50 \mathrm{H}, 6 \mathrm{H}+\mathrm{H}_{1 \beta}\right) ; 4.44(\mathrm{~d}, J=$ $\left.7.9 \mathrm{~Hz}, 0.50 \mathrm{H}, \mathrm{H}_{1 \alpha}\right) ; 4.40(\mathrm{~m}, 1 \mathrm{H}) ; 4.17(\mathrm{~m}, 1 \mathrm{H}) ; 4.02(\mathrm{~m}, 1 \mathrm{H}) ; 3.94(\mathrm{~s}, 3 \mathrm{H}) ; 3.86-3.35(\mathrm{~m}, 12 \mathrm{H})$; $2.56(\mathrm{~m}, 2 \mathrm{H}) ; 2.34-1.98(\mathrm{~m}, 5 \mathrm{H}) ; 1.84(\mathrm{~m}, 2 \mathrm{H}) ; 1.51-1.47(\mathrm{~m}, 3 \mathrm{H}) ; 1.30(\mathrm{~s}, 3 \mathrm{H}) ; 0.99(\mathrm{~m}, 12 \mathrm{H})$; ${ }^{13} \mathrm{C}$ NMR $\left(75 \mathrm{MHz}, \mathrm{CD}_{3} \mathrm{OD}\right): \delta=174.1,173.0,171.0,171.5,171.0165 .4,155.6,140.2,140.0$, $139.9,139.7,139.5,133.5,129.4-128.5,126.8,124.3,121.0,113.4,104.8\left(\mathrm{C}_{1 \mathrm{H} \alpha}\right), 98.0\left(\mathrm{C}_{1 \mathrm{H} \beta}\right)$, $85.7,83.2,83.0,81.4,79.0,76.4,76.0,75.9,75.6,73.9,71.770 .6,68.5,68.3,68.2,67.3,60.7$, $58.8,56.9,50.3,49.9,38.0,37.6,37.5,32.0,31,9,30.4,30.4,23.6,19.8,19.0,18.9,18.7,17.8$; HRMS (TOF, ESI, ion polarity positive, $\mathrm{H}_{2} \mathrm{O} / \mathrm{MeOH}$ ): $\mathrm{m} / \mathrm{z}[\mathrm{M}+\mathrm{H}]^{+}$, calcd for $\mathrm{C}_{56} \mathrm{H}_{76} \mathrm{~N}_{7} \mathrm{O}_{13}$ 1054.5501; found 1054.5524, $\mathrm{m} / \mathrm{z}[\mathrm{M}+\mathrm{Na}]^{+}$, calcd for $\mathrm{C}_{56} \mathrm{H}_{75} \mathrm{~N}_{7} \mathrm{O}_{13} \mathrm{Na}$ 1076.5321; found 1076.5360; HPLC purity: TR $(\alpha, \beta)=18.77,19.24$ min., $96.1 \%$.

Benzyl $N$-[(5S)-6-[2-(5-acetamido-2-methoxy-benzoyl)hydrazino]-5-[3-[[(3R,4S,5S)-6-[3[[(2S)-2-[[(2S)-2-aminopropanoyl]amino]-3-methyl-butanoyl]amino]propoxy]-3,4,5-

tribenzyloxy-tetrahydropyran-2-yl]methoxy]propanoylamino]-6-oxo-hexyl]carbamate (23). Same procedure as described for $\mathbf{1 6 a}$ from $19(38 \mathrm{mg}, 0.029 \mathrm{mmol})$ in dry $\mathrm{CH}_{2} \mathrm{Cl}_{2}(220 \mu \mathrm{L})$, to afford 23 as a white solid (35.5 mg, quantitative, $\alpha / \beta$ 50/50). $\mathrm{R}_{\mathrm{f}}=0\left(\mathrm{CH}_{2} \mathrm{Cl}_{2} / \mathrm{CH}_{3} \mathrm{OH}: 95 / 5\right) ;{ }^{1} \mathrm{H}$ NMR $\left(300 \mathrm{MHz}, \mathrm{CDCl}_{3}\right): \delta=11.10(\mathrm{sl}, 1 \mathrm{H}) ; 10.65(\mathrm{~m}, 1 \mathrm{H}) ; 9.52(\mathrm{~m}, 1 \mathrm{H}) ; 8.50-8.01(\mathrm{~m}, 7 \mathrm{H})$; 7.32- $7.25(\mathrm{~m}, 21 \mathrm{H},) ; 6.84(\mathrm{~m}, 1 \mathrm{H}) ; 5.25-4.49\left(\mathrm{~m}, 11.50 \mathrm{H}, 11 \mathrm{H}+\mathrm{H}_{1 \beta}\right) ; 4.36\left(\mathrm{~m}, 1.50 \mathrm{H}, 1 \mathrm{H}+\mathrm{H}_{1 \alpha}\right)$; $3.87(\mathrm{~s}, 3 \mathrm{H}) ; 3.78-2.93(\mathrm{~m}, 16 \mathrm{H}) ; 2.51(\mathrm{~s}, 2 \mathrm{H}) ; 2.11(\mathrm{~s}, 3 \mathrm{H}) ; 1.96-1.81(\mathrm{~m}, 5 \mathrm{H}) ; 1.50(\mathrm{~s}, 3 \mathrm{H})$; $1.44(\mathrm{~m}, 4 \mathrm{H}) ; 0.88-0.85(\mathrm{~m}, 6 \mathrm{H}) ;{ }^{13} \mathrm{C} \mathrm{NMR}\left(75 \mathrm{MHz}, \mathrm{CDCl}_{3}\right): \delta=173.2,172.0,171.5,171.3$ $169.9,165.5,158.8,153.6,138.6,138.2,138.6,138.0,136.6,136.5,135.9,133.0,128.4$, 
$128.3,127.9,127.8,127.7,127.6,125.8,122.9,117.6,111.9,103.9\left(\mathrm{C}_{1 \mathrm{H} \alpha}\right), 97.1\left(\mathrm{C}_{1 \mathrm{H \beta}}\right), 84.4$, $82.1,81.8,80.0,78.2,77.5,75.5,74.9,74.7,74.6,72.9,69.6,67.6,66.5,59.3,59.1,56.3,51.3$, 50.0, 49.6, 40.5, 36.7, 36.5, 36.2, 32.6, 31.4, 29.2, 23.9, 22.4, 19.0, 18.4, 17.3 ; HRMS (TOF, ESI, ion polarity positive, $\left.\mathrm{H}_{2} \mathrm{O} / \mathrm{MeOH}\right): \mathrm{m} / \mathrm{z}[\mathrm{M}+\mathrm{H}]^{+}$, calcd for $\mathrm{C}_{65} \mathrm{H}_{85} \mathrm{~N}_{8} \mathrm{O}_{15}$ 1217.6134; found 1217.6168, $\mathrm{m} / \mathrm{z}[\mathrm{M}+\mathrm{Na}]^{+}$, calcd for $\mathrm{C}_{65} \mathrm{H}_{84} \mathrm{~N}_{8} \mathrm{O}_{15} \mathrm{Na}$ 1239.5954; found 1239.5972, HPLC purity: $\operatorname{TR}(\alpha, \beta)=19.24,19.67 \mathrm{~min} ., 91.1 \%$.

\section{Fluorescence-detected Thioflavin-T binding assay}

Thioflavin $T$ was obtained from Sigma. $A \beta_{1-42}$ was purchased from American Peptide. The peptide was dissolved in an aqueous $1 \%$ ammonia solution to a concentration of $1 \mathrm{mM}$ and then, just prior to use, was diluted to $0.2 \mathrm{mM}$ with $10 \mathrm{mM}$ Tris- $\mathrm{HCl}, 100 \mathrm{mM} \mathrm{NaCl}$ buffer (pH 7.4). Stock solutions of glycopeptides were dissolved in DMSO with the final concentration kept constant at $0.5 \%(\mathrm{v} / \mathrm{v})$.

Thioflavin $T$ fluorescence was measured to evaluate the development of $A \beta_{1-42}$ fibrils over time using a fluorescence plate reader (Fluostar Optima, BMG labtech) with standard 96-well black microtiter plates. Experiments were started by adding the peptide (final A $\beta 1-42$ concentration equal to $10 \mu \mathrm{M}$ ) into a mixture containing $40 \mu \mathrm{M}$ Thioflavin $\mathrm{T}$ in $10 \mathrm{mM}$ Tris$\mathrm{HCl}, 100 \mathrm{mM} \mathrm{NaCl}$ buffer $(\mathrm{pH}$ 7.4) with and without the tested compounds at different concentrations $(100,50,10,1 \mu \mathrm{M})$ at room temperature. The Th-T fluorescence intensity of each sample (performed in duplicate or triplicate) was recorded with 440/485 nm excitation/emission filters set for 42 hours performing a double orbital shaking of $10 \mathrm{~s}$. before the first cycle. The fluorescence assays were performed between 2 and 4 times on different days, with the same batch of peptide. The ability of compounds to inhibit/accelerate A $\beta 1-42$ aggregation was assessed considering both the time of the half-life of aggregation (t1/2) and the intensity of the 
experimental fluorescence plateau (F). The relative extension (or reduction) of $t 1 / 2$ is defined as the experimental $t 1 / 2$ in the presence of the tested compound relative to the one obtained without the compound and is evaluated as the following percentage: $t 1 / 2(\mathrm{~A} \beta+$ compound $) / t 1 / 2(\mathrm{~A} \beta) \mathrm{x}$ 100. The decrease (or increase) of the experimental plateau is defined as the intensity of experimental fluorescence plateau observed with the tested compound relative to the value obtained without the compound and is evaluated as the absolute value of following percentage : FA $\beta$ - FA $\beta+$ compound $\mid / F A \beta \times 100$ (a decrease is indicated with a (-) and an increase with a $(+)$.

\section{Transmission electron microscopy}

Samples were prepared under the same conditions as in the ThT-fluorescence assay. Aliquots of $\mathrm{A} \beta_{1-42}(10 \mu \mathrm{M}$ in $10 \mathrm{mM}$ Tris- $\mathrm{HCl}, 100 \mathrm{mM} \mathrm{NaCl} \mathrm{NaCl}, \mathrm{pH} 7.4$ in the presence and absence of the tested compounds) were adsorbed onto 300-mesh carbon grids for $2 \mathrm{~min}$, washed and dried. The samples were negatively stained for 45 s. on $2 \%$ uranyl acetate in water. After draining off the excess of staining solution and drying, images were obtained using a ZEISS 912 Omega electron microscope operating at an accelerating voltage of $80 \mathrm{kV}$.

\section{Capillary electrophoresis}

Sample preparation: the commercial $A \beta_{1-42}$ was dissolved upon reception in $0.16 \% \mathrm{NH} 4 \mathrm{OH}$ (at $2 \mathrm{mg} / \mathrm{mL}$ ) for 10 minutes at $20^{\circ} \mathrm{C}$, followed by an immediate lyophilization. The dried sample was then stored at $-20^{\circ} \mathrm{C}$ until use.

CE experiments were carried out with a P/ACE TM MDQ Capillary Electrophoresis System (Beckman Coulter Inc., Brea, CA, USA) equipped with a photodiode array detector. UV Detection was performed at $190 \mathrm{~nm}$. The sample (as previously described) was reconstituted by dissolution in $20 \mathrm{mM}$ phosphate buffer $\mathrm{pH} 7.4$ containing DMSO (control or stock solutions of 
glycopeptidomimetic dissolved in DMSO). A constant DMSO/phosphate buffer ratio at $2.5 \%$ (v/v) was used for each sample. The final peptide concentration was set at $100 \mu \mathrm{M}$ regardless the peptide/compound ratio.

For the $\mathrm{CE}$ separation of $\mathrm{A} \beta$ oligomers, fused silica capillary $60 \mathrm{~cm}(10.2 \mathrm{~cm}$ to the detector $)$ $50 \mu \mathrm{m}$ I.D. were used. The background electrolyte was a $80 \mathrm{mM}$ phosphate buffer, $\mathrm{pH}$ 7.4. The separation was carried out under $-20 \mathrm{kV}$ at $25^{\circ} \mathrm{C}$. The sample was injected from the outlet by hydrodynamic injection at $0.5 \mathrm{psi}$ for $10 \mathrm{~s}$. After each run, the capillary was rinsed for $3.5 \mathrm{~min}$ with $\mathrm{NaOH} 1 \mathrm{M}, 3.5 \mathrm{~min}$ with water, 1 min with DMSO $10 \%$, 1 min with SDS $50 \mathrm{mM}$, and equilibrated with running buffer for $3 \mathrm{~min}$.

\section{NMR spectroscopy}

NMR experiments were recorded on a Bruker Avance III $500 \mathrm{MHz}$ spectrometer equipped with a ${ }^{1} \mathrm{H} /{ }^{13} \mathrm{C} /{ }^{15} \mathrm{~N}$ TCI cryoprobe with $\mathrm{Z}$-axis gradient. NMR spectra were processed and analysed with TopSpin software (Bruker).

The conformation of $\mathbf{3 \beta}$ was studied in aqueous solution, either in $\mathrm{H}_{2} \mathrm{O} / \mathrm{D}_{2} \mathrm{O}(90 / 10 \mathrm{v} / \mathrm{v})$ or in $50 \mathrm{mM}$ sodium phosphate, $\mathrm{pH} 7.4$ containing $10 \% \mathrm{D}_{2} \mathrm{O} .{ }^{1} \mathrm{H}$ and ${ }^{13} \mathrm{C}$ resonances were assigned using 1D ${ }^{1} \mathrm{H}$ WATERGATE, 2D ${ }^{1} \mathrm{H}-{ }^{1} \mathrm{H}$ TOCSY (MLEV17 isotropic scheme of $68 \mathrm{~ms}$ duration), 2D ${ }^{1} \mathrm{H}-{ }^{1} \mathrm{H}$ ROESY (500 ms mixing time), 2D ${ }^{1} \mathrm{H}-{ }^{13} \mathrm{C}$ HSQC, and 2D $1 \mathrm{H}-{ }^{13} \mathrm{C}$ HMBC spectra. ${ }^{1} \mathrm{H}$ and ${ }^{13} \mathrm{C}$ chemical shifts were calibrated using DSS (sodium 4,4-dimethyl-4-silapentane-1sulfonate) as an internal reference. The ${ }^{1} \mathrm{H}$ and ${ }^{13} \mathrm{C}$ resonance assignments of $\mathbf{3 \beta}$ are listed in Tables S1 and S2. Vicinal coupling constants were extracted from 1D ${ }^{1} \mathrm{H}$ WATERGATE. The temperature gradients of the amide proton chemical shifts were derived from $1 \mathrm{D}{ }^{1} \mathrm{H}$ WATERGATE spectra recorded between $5{ }^{\circ} \mathrm{C}$ and $30^{\circ} \mathrm{C}$. 
Samples of $A \beta_{1-42}$ in the absence or in the presence of $\mathbf{3} \boldsymbol{\beta}$ were prepared in Shigemi tubes (280 $\mu \mathrm{L}$ volume) in $50 \mathrm{mM}$ sodium phosphate, $\mathrm{pH} 7.4$ containing $10 \% \mathrm{D} 2 \mathrm{O}$. Synthetic $\mathrm{A} \beta_{1-42}$ peptide was used in NMR experiments, with the exception of 2D HSQC experiments requiring ${ }^{15} \mathrm{~N},{ }^{13} \mathrm{C}$ labelled recombinant $A \beta_{1-42}$. Solid phase peptide synthesis of $A \beta 1-42$ was performed at the Institut de Biologie Intégrative (IFR83- Université Pierre et Marie Curie). Recombinant A $\beta_{1-42}$ was obtained according to the protocol of Walsh et al.35 NMR experiments were acquired at $5{ }^{\circ} \mathrm{C}$. 2D NOESY experiments were recorded with a mixing time of $0.2 \mathrm{~s} .1 \mathrm{D}{ }^{1} \mathrm{H}$ STD experiments were acquired using a cascade of Gaussian shaped pulses (50 ms pulse, B1 field of $0.1 \mathrm{kHz}$, total duration of $3 \mathrm{~s})$ applied on resonance $(-0.7 \mathrm{ppm})$ and off resonance $(+30 \mathrm{ppm})$, alternatively. The number of scans was set to 320 , corresponding to an experiment duration of 50 min. 1D ${ }^{1} \mathrm{H}$ WaterLOGSY (water-ligand observed via gradient spectroscopy) experiments were recorded using a Gaussian pulse of $20 \mathrm{~ms}$ duration for selective inversion of water magnetization and a mixing period of $0.5 \mathrm{~s}$. The recycling delay was set to $2 \mathrm{~s}$ and the total number of scans was 1200 , corresponding to an experimental time of 1 hour.

\section{SPR experiments}

For these studies we used the Biacore T100 (GE Healthcare, France) apparatus, which has 4 parallel flow channels. $A \beta_{1-42}$ peptide was immobilized on the carboxy-terminated dextran matrix on gold surface sensor chip (CM5 sensor chip, GE Healthcare, France) by an optimized amine coupling method. Briefly, the surface was treated with a mixture of $0.4 \mathrm{M}$ EDC and $0.1 \mathrm{M}$ NHS $(1 / 1)$ in water for $7 \mathrm{~min}$. at $10 \mu \mathrm{L} / \mathrm{min}$. Then, a freshly prepared $\mathrm{A} \beta_{1-42}$ solution $(0.05 \mu \mathrm{M})$ in a 10 $\mathrm{mM}$ sodium acetate buffer ( $\mathrm{pH} 4.6)$ was injected 4 times during $15 \mathrm{~min}$. each at $10 \mu \mathrm{L} / \mathrm{min}$ on the NHS-activated surface. Then, a final injection of ethanolamine was done to block the nonlinked activated amine. A reference surface was prepared using the same immobilization 
procedure but with an ethanolamine injection instead of the peptide (blank surface). At that point of the process, the fixation lead to a SPR signal of 3000 RU. A rinsing step using an aqueous solution of $\mathrm{NH}_{4} \mathrm{OH} . \mathrm{H}_{2} \mathrm{O} 0.1 \%$ (9 injections of 1 min. each at $30 \mu \mathrm{L} / \mathrm{min}$.) was performed in order to remove from the surface all the $A \beta_{1-42}$ aggregates that may have been formed during the immobilization step. After these rinsing steps, the chip gave a signal of about 1500 RU.

Binding of compounds $\mathbf{3 \beta}, \mathbf{1}$ and curcumin to $A \beta_{1-42}$ fixed on the SPR chips : Solutions of compounds in $150 \mathrm{mM}$ PBS containing 2\% DMSO solubilized in DMSO were injected on the $\mathrm{A} \beta_{1-42}$ surface for $1 \mathrm{~min}$. at $80 \mu \mathrm{L} / \mathrm{min}$. The rinsing step was performed using the running buffer for $5 \mathrm{~min}$. and the regeneration step using the aqueous solution of $\mathrm{NH}_{4} \mathrm{OH} . \mathrm{H}_{2} \mathrm{O} 0.1 \%$ (3 times for $5 \mathrm{~min}$ at $30 \mu \mathrm{L} / \mathrm{min}$.). The range of concentrations started from $12.5 \mu \mathrm{M}$ and ended at 200 $\mu \mathrm{M}$ in PBS (150 mM), 2\% DMSO. A DMSO solvent correction was applied to the raw signals and non-specific signal was subtracted using the blank channel.

\section{Cell toxicity}

SH-SY5Y neuroblastoma cells were grown in low serum Optimem (Life Technologies) for 24 hours at $37^{\circ} \mathrm{C}, 5 \% \mathrm{CO} 2$ in a 96 well plate at 20000 cells per well. $\mathrm{A} \beta_{1-42}$ was dissolved in sterile PBS at $50 \mu \mathrm{M}$ concentration in the presence of $1,5,10$ and $50 \mu \mathrm{M}$ of either 1 or 3 for 24 hours at room temperature, along with a control incubation with no inhibitor. After the 24 hour period, media was removed from the cells and replaced with Optimem containing the pre-incubated $\mathrm{A} \beta_{1 \text { - }}$ 42 plus inhibitor diluted one in ten $(5 \mu \mathrm{M} \mathrm{A} \beta$ final concentration) in quadruplicate. The cells were incubated for a further 24 hours as before and the cell viability (MTS assay) and cell proliferation (LDH assay) assessed using the CellTiter 96® Aqueous One Solution Cell Proliferation Assay (Promega) and CytoTox 96® Non-Radioactive Cytotoxicity Assay (Promega) respectively. The assays were repeated twice and representative samples are shown. 


\section{Plasma stability}

Both 1 and 3 were dissolved at $40 \mu \mathrm{M}$ in DMSO and then diluted to $1 \mu \mathrm{M}$ in $10 \%$ human plasma, 90\% sterile PBS. One hundred microlitre samples were run on an HPLC system (Dionex, with C18 Jupiter column from Phenomenex) using a gradient of 0-80\%B (Buffer A: 0.1\% trifluoroacetic acid in water, Buffer B: 0.05\% trifluoroacetic acid in acetonitrile). Samples were monitored at $230 \mathrm{~nm}$. After 24 hour incubation at $37^{\circ} \mathrm{C} 100 \mu \mathrm{L}$ samples were run on the same gradient and monitored as before.

\section{ASSOCIATED CONTENT}

Supporting Information. NMR assignments of 3ß; representative NMR spectra and HPLC purities, experimental procedure for fluorescence-detected ThT binding assay on $\mathrm{A} \beta_{1-42}$ and IAPP; representative curves of ThT fluorescence assays; experimental procedure for TEM, CE, NMR and SPR.

\section{AUTHOR INFORMATION}

\section{Corresponding Author}

* E-mail : $\underline{\text { Sandrine.ongeri@u-psud.fr. }}$

Phone : +33146835737.

\section{Author Contributions}

The manuscript was written through contributions of all authors. All authors have given approval to the final version of the manuscript. 


\title{
Funding Sources
}

The Ministère de l'Enseignement Supérieur et de la Recherche (MESR) is thanked for financial support for DB. The European Union is thanked for funding the research training of NT, KF, CB and YI in the frame of the European student exchange Erasmus programme.

The Laboratory BioCIS is a member of the Laboratory of Excellence LERMIT supported by a Grant from ANR (ANR-10-LABX-33).

\section{ACKNOWLEDGMENT}

Chiara Bernardi (CB) (BioCIS, UMR 8076) is thanked for her help with the synthesis. Claire Troufflard and Karine Leblanc (BioCIS, UMR 8076) are thanked for their help with the NMR experiments and the HPLC analysis respectively. Magali Noiray (CIBLOT-Bia, Université ParisSud) and Géraldine Toutirais (Institut de Biologie Paris Seine (IBPS)/ FR3631, Service de Microscopie Electronique, Université Pierre et Marie Curie, France) are acknowledged for their advices in SPR and TEM experiments respectively.

\author{
ABBREVIATIONS \\ A $\beta$, Amyloid-beta peptide; AD, Alzheimer's disease; CE, Capillary Electrophoresis; STD, \\ Saturation Transfer Difference; ThT, Thioflavin T; TEM, Transmission Electron Microscopy; \\ SPR, Surface Plasmon resonance; SAR, Structure-activity relationships; DMTMM, [4-(4,6- \\ Dimethoxy1,3,5-triazin-2-yl)-4-methyl-morpholinium $\quad$ tetrafluoroborate]; $\quad$ DMAP, 4- \\ dimethylaminopyridine.
}




\section{REFERENCES}

(1) (a) Alzheimer's disease international. World Alzheimer Reports. http://www.alz.co.uk/research/world-report (accessed december 14th, 2015). (b) Mucke, L. Neuroscience : Alzheimer's disease. Nature 2009, 461, 895-897.

(2) (a) Goedert, M.; Spillantini, M. G. A Century of Alzheimer's Disease. Science 2006, 314, 777-780. (b) Haas, C. ; Selkoe, D. J. Soluble protein oligomers in neurodegeneration : lessons from the Alzheimer amyloid $\beta$-peptide. Nat. Rev. Mol. Cell Biol. 2007, 8, 101-112.

(3) Cohen, S. I. A.; Linse, S.; Luheshi, M.; Hellstrand, E.; White, D. A.; Rajah, L.; Otzen, D. L.; Vendruscolo, M.; Dobson, C. M.; Knowles, T. P. J. Proliferation of amyloid- $\beta 42$ aggregates occurs through a secondary nucleation mechanism. Proc. Natl. Acad. Sci. USA. 2013, 110, 97589763.

(4) Matsumura, S.; Shinoda, K.; Yamada, M.; Yokojima, S.; Inoue, M.; Ohnishi, T; Shimada, T.; Kikuchi, K.; Masui, D.; Hashimoto, S.; Sato, M.; Ito, A.; Akioka, M.; Takagi, S.; Nakamura, Y.; Nemoto, K.; Hasegawa, Y.; Takamoto, H.; Inoue, H.; Nakamura, S.; Nabeshima,Y.; Teplow, D.B.; Kinjo, M.; Hoshi, M. Two distinct amyloid $\beta$-protein $(A \beta)$ assembly pathways leading to oligomers and fibrils identified by combined fluorescence correlation spectroscopy, morphology, and toxicity analyses. J. Biol. Chem. 2011, 286, 11555-11562.

(5) Jeong, J. S.; Ansaloni, A.; Mezzenga, R.; Lashuel, H. A.; Dietler, G. Novel mechanistic insight into the molecular basis of amyloid polymorphism and secondary nucleation during amyloid formation. J. Mol. Biol. 2013, 425, 1765-1781. 
(6) Lührs, T.; Ritter, C.; Adrian, M.; Riek-Loher, D.; Bohrmann, B.; Döbeli, H.; Schubert, D.; Riek, R. 3D structure of Alzheimer's amyloid- $\beta(1-42)$ fibrils. Proc. Natl. Acad. Sci. USA. 2005, $102,17342-17347$.

(7) Laganowsky, A.; Liu, C.; Sawaya, R. M.; Whitelegge, J. P.; Park, J.; Zhao, M. Atomic view of a toxic amyloid small oligomer. Science 2012, 335, 1228-1231.

(8) Yu, L.; Edalji, R.; Harlan, J. E.; Holzman, T. F.; Pereda Lopez, A.; Labkovsky, B.; Hillen, H.; Barghorn, S.; Ebert, U.; Richardson, P.L.; Miesbauer; L.; Solomon, L.; Bartley, D.; Walter, K.; Johnson, R.W.; Hajduk, P.J.and Olejniczak, E.T. Structural characterization of a soluble amyloid $\beta$-peptide oligomer. Biochemistry 2009, 48, 1870-1877.

(9) Ahmed, M.; Davis, J.; Aucoin, D.; Sato, D.; Ahuja, S.; Aimoto, S.; Elliott, J. J.; Van Nostrand W. E.; O Smith. Structural conversion of neurotoxic amyloid- $\beta 1-42$ oligomers to fibrils. Nat. Struct. Mol. Biol. 2010, 17, 561-567.

(10) Wälti M. A.; Orts J.; Vçgeli B.; Campioni S.; Riek R. Solution NMR Studies of recombinant $A \beta(1-42)$ : from the presence of a micellar entity to residual $\beta$-sheet structure in the soluble species. ChemBioChem 2015, 16, 659-669.

(11) Dahlgren, K. N.; Manelli, A. M.; Blaine Stine, W.; Baker, L. K.; Krafft, G. A; LaDu, M. J. Oligomeric and fibrillar species of amyloid- $\beta$ peptides differentially affect neuronal viability. $J$. Biol. Chem. 2002, 277, 32046-32053.

(12) Jan, A.; Gokce, O.; Luthi-Carter R.; Lashuel, H. A. The ratio of Monomeric to Aggregated forms of $A \beta 40$ and $A \beta 42$ is an important determinant of amyloid- $\beta$ aggregation, fibrillogenesis, and toxicity. J. Biol. Chem. 2008, 283, 28176-28189. 
(13) Ono, K.; Condron, M. M.; Teplow, D. B. Structure-neurotoxicity relationships of amyloid ß-protein oligomers. Proc. Natl. Acad. Sci. USA. 2009, 106, 14745-14750.

(14) Shankar, G. M.; Li, S.; Mehta, T. H.; Garcia-Munoz A.; Shepardson, N. E.; Smith I.; Brett, F.M.; Farrell, M.A.; Rowan, M.J.; Lemere, C.A.; Regan; C.M.; Walsh, D.M.; Sabatini, B.L. and Selkoe, D.J. Amyloid $\beta$-protein dimers isolated directly from Alzheimer brains impair synaptic plasticity and memory. Nat. Med. 2008, 14, 837-842.

(15) Prangkio, P.; Yusko, E. C.; Sept, D.; Yang, J.; Mayer, M. Multivariate analyses of amyloid-beta oligomer populations indicate a connection between pore formation and cytotoxicity. PLoS ONE 2012, 7, 47261.

(16) Cizas, P.; Budvytyte, R.; Morkuniene, R.; Moldovan, R.; Broccio, M.; Lösche, M.; Niaura, G.; Valincius, G.; Borutaite,V. Size-dependent neurotoxicity of $\beta$-amyloid oligomers. Arch. Biochem. Biophys. 2010, 496, 84-92.

(17) Mayes, J.; Tinker-Mill, C.; Kolosov, O.; Zhang, H.; Tabner, B. J.; Allsop, D. $\beta$-Amyloid fibrils in Alzheimer's disease are not inert when bound to copper ions but can degrade hydrogen peroxide and generate reactive oxygen species. J Biol Chem. 2014, 289, 12052-12062.

(18) Cohen, S. I. A.; Linse, S.; Luheshi, L. M.; Hellstrand, E.; White, D. A.; Rajah, L.; Otzen, D. E.; Vendruscolo, M.; Dobson, C. M.; Knowles, T. P. J. Proliferation of amyloid- $\beta 42$ aggregates occurs through a secondary nucleation mechanism. Proc Natl Acad Sci U S A. 2013, 110, $9758-9763$.

(19) (a) Belluti, F.; Rampa, A.; Gobbi, S.; Bisi, A. Small-molecule inhibitors/modulators of amyloid- $\beta$ peptide aggregation and toxicity for the treatment of Alzheimer's disease: a patent 
review (2010 - 2012). Expert Opin. Ther. Pat. 2013, 23, 581-596. (b) Härd, T.; Lendel, C. Inhibition of amyloid formation. J. Mol. Biol. 2012, 421, 441-465. (c) Doig, A. J.; Derreumaux P. Inhibition of protein aggregation and amyloid formation by small molecules. Curr. Opin. Struct. Biol. 2015, 30, 50-56.

(20) (a) Stains, C.I.; Mondal, K.; Ghosh, I. Molecules that target beta-Amyloid. ChemMedChem. 2007, 2, 1674-1692. (b) Takahashi, T.; Mihara, H. Mimetics. Peptide and protein mimetics inhibiting amyloid peptide aggregation. Acc. Chem. Res. 2008, 41, 1309-1318. (c) Neddenriep, B.; Calciano, A.; Conti, D.; Sauve, E.; Paterson, M.; Bruno, E.; Moffet, D. A. Short peptides as inhibitors of amyloid aggregation. Open Biotechnol. J. 2011, 5, 39-46. (d) Luo, J.; Abrahams. J. P. Cyclic peptides as inhibitors of amyloid fibrillation. Chem. Eur. J. 2014, 20, 2410-2419.

(21) Cheng, P.-N.; Liu, C.; Zhao, M.; Eisenberg, D.; Nowick, J. S. Amyloid $\beta$-sheet mimics that antagonize protein aggregation and reduce amyloid toxicity. Nat. Chem. 2012, 4, 927-933.

(22) Taylor, M.; Moore, S.; Mayes, J.; Parkin, E.; Beeg, M.; Canovi, M.; Gobbi, M.; Mann, D. M. A.; Allsop, D. Development of a proteolytically stable retro-inverso peptide inhibitor of $\beta$ amyloid oligomerization as a potential novel treatment for Alzheimer's disease. Biochemistry 2010, 49, 3261-3272.

(23) Arai, T.; Araya, T.; Sasaki, D.; Taniguchi, A.; Sato, T.; Sohma, Y.; Kanai, M. Rational Design and identification of a non-peptidic aggregation inhibitor of amyloid- $\beta$ based on a pharmacophore motif obtained from cyclo[-Lys-Leu-Val-Phe-Phe-]. Angew. Chem. Int. Ed. 2014, 53, 8236-8239. 
(24) (a) Dorgeret, B.; Khémtemourian, L.; Correia, I.; Soulier, J-L; Lequin, O. ; Ongeri, S. Sugar-based peptidomimetics inhibit amyloid $\beta$-peptide aggregation. Eur. J. Med. Chem. 2011, 46, 5959-5969. (b) Kaffy, J.; Brinet, D.; Soulier, J-L; Khemtémourian, L.; Lequin, O.; Taverna, M.; Crousse, B.; Ongeri, S. Structure-activity relationships of sugar-based peptidomimetics as modulators of amyloid $\beta$-peptide early oligomerization and fibrillization. Eur. J. Med. Chem. 2014, $86,752-758$.

(25) (a) Gruner, S. A. W.; Truffault, V.; Voll, G.; Locardi, E.; Stöckle, M.; Kessler, H. Design, Synthesis, and NMR structure of linear and cyclic oligomers containing novel furanoid sugar amino acids. Chem. Eur. J. 2002, 8, 4366-4376. (b) Schweizer, F. Glycosamino acids: building blocks for combinatorial synthesis-implications for drug discovery. Angew. Chem. Int. Ed. 2002, 41, 230-253. (c) Risseueuw, M. D. P.; Overhand, M.; Fleet, G. W. J.; Simone, M. I. A compendium of sugar amino acids (SAA): scaffolds, peptide- and glyco-mimetics. Tetrahedron: Asymmetry 2007, 18, 2001-2010.

(26) Nowick, J. S.; Chung, D. M.; Maitra, K.; Maitra, S.; Stigers, K. D.; Sun, Y. An unnatural amino acid that mimics a tripeptide $\beta$-strand and forms $\beta$-sheet like hydrogen-bonded dimers. $J$. Am. Chem. Soc. 2000, 122, 7654-7661.

(27) (a) Bannwarth, L.; Kessler, A.; Pèthe, S.; Collinet, B.; Merabet, N.; Boggetto, N.; Sicsic, S.; Reboud-Ravaux, M.; Ongeri, S. Molecular tongs containing amino acid mimetic fragments : new inhibitors of wild-type and mutated HIV-1 protease dimerization. J. Med. Chem. 2006, 49, 4657-4664. (b) Vidu, A.; Dufau, L.; Bannwarth, L.; Soulier, J-L; Sicsic, S.; Piarulli, U.; ReboudRavaux, M.; Ongeri, S. Towards the first non peptidic molecular tong inhibitor of wild-type and mutated HIV-1 protease dimerization. ChemMedChem 2010, 5, 1899-1906. 
(28) (a) Yamanoi, T.; Inoue, R.; Matsuda, S.; Iwao, K.; Oda, Y.; Yoshida, A.; Hamasaki, K. Formation of O-glycosidic linkages from 1-hydroxy sugars by bismuth(III) triflate-catalyzed dehydrative glycosidation. Heterocycles 2009, 77, 445-460. (b) Yamazaki, T.; Sugawara, F.; Ohta, K.; Masaki, K.; Nakayama, K.; Sakaguchi, K.; Sato, N.; Sahara, H.; Fujita, T. Novel sulfoquinovosylacylglycerol derivative, and use thereof as medicaments. US. Patent Appl. Publ. 2002, US 20020052327 A1.

(29) (a) Kaminski, Z.J.; Kolesinska B.; Kolesinska, J.; Sabatino, G.; Chelli, M.; Rovero, P.; Błaszczyk, M.; Głowka, M.L.; and Papini, A.M. N-Triazinylammonium tetrafluoroborates. A new generation of efficient coupling reagents useful for peptide synthesis. J. Am. Chem. Soc. 2005, 127, 16912-16920. (b) Jastrzabek K.G.; Subiros-Funosas, R.; Albericio, F.; Kolesinska, B.; and Kaminski , Z.J. 4-(4,6-Di[2,2,2-trifluoroethoxy]-1,3,5-triazin-2-yl)-4-methylomor-pholinium tetrafluoroborate. Triazine-based coupling reagents designed for coupling sterically hindered substrates. J. Org. Chem. 2011, 76, 4506-4513.

(30) Komarova, B. S.; Maryasina, S. S.; Tsvetkov, Y. E.; Nifantiev, N. E. Water-dependent reduction of carbohydrate azides by dithiothreitol. Synthesis 2013, 45, 471-478.

(31) LeVine 3rd, H. Quantification of $\beta$-sheet amyloid fibril structures with thioflavin T. Methods Enzymol. 1999, 309, 274-284.

(32) Brinet, D.; Kaffy, J.; Oukacine, F.; Glumm, S.; Ongeri, S.; Taverna, M. An improved CE method for the in vitro monitoring of the challenging early steps of the $A \beta_{1-42}$ peptide oligomerization: application to anti-Alzheimer's drug discovery. Electrophoresis 2014, 35, 33023309. 
(33) Fawzi, N.L.; Ying, J.; Ghirlando, R.; Torchia, D.A.; Clore, G.M. Atomic-resolution dynamics on the surface of amyloid- $\beta$ protofibrils probed by solution NMR. Nature 2011, 480, $268-272$.

(34) Walsh, D.M.; Thulin, E.; Minogue, A.M.; Gustavsson, N.; Pang, E.; Teplow, D.B.; Linse, S. A facile method for expression and purification of the Alzheimer's disease-associated amyloid $\beta$-peptide. FEBS J. 2009, 276, 1266-1281.

(35) Airoldi, C.; Cardona, F.; Sironi, E.; Colombo, L.; Salmona, M.; Silva, A.; Nicotra, F.; La Ferla, B. cis-Glyco-fused benzopyran compounds as new amyloid- $\beta$ peptide ligands. Chem. Commun. 2011, 47, 10266-10268.

(36) Taniguchi, A.; Sohma, Y.; Hirayama, Y.; Mukai, H.; Kimura, T.; Hayashi, Y.; Matsuzaki, K.; Kiso, Y. "Click peptide": pH-triggered in situ production and aggregation of monomer Abeta1-42. ChemBioChem 2009, 10, 710-715.

(37) Canovi, M.; Lucchetti, J.; Stravalaci, M.; Re, F.; Moscatelli, D.; Bigini, P.;Salmona, M.; Gobbi, M. Applications of surface plasmon resonance (SPR) for the characterization of nanoparticles developed for biomedical purposes. Sensors 2012, 12, 16420-16432.

(38) (a) Amijee, H.; Bate, C.; Williams, A.; Virdee, J.; Jeggo, R.; Spanswick, D.; Scopes, D.I.C.; Treherne, J.M.; Mazzitelli, S.; Chawner, R.; Eyers, C.E.; Doig, A.J. The N-methylated peptide SEN304 powerfully inhibits $A \beta(1-42)$ toxicity by perturbing oligomer formation. Biochemistry 2012, 51, 8338-8352. (b) Maezawa, I.; Hong, H-S.; Liu, R.; Wu, C-Y.; Cheng, RH.; Kung, M-P.; Kung, H.F.; Lam, K.S.; Oddo, S.; LaFerla, F.M.; Jin, L-W. Congo red and thioflavin-T analogs detect A $\beta$ oligomers. J. Neurochem. 2008, 104, 457-468. 
(39) Stravalaci, M.; Bastone, A.; Beeg, M.; Cagnotto, A.; Colombo, L.; Di Fede, G.; Tagliavini, F.; Cantù, L.; Del Favero, E.; Mazzanti, M.; Chiesa, R.; Salmona, M.; Diomede, L.; Gobbi, M. Specific recognition of biologically active amyloid- $\beta$ oligomers by a new surface plasmon resonance-based immunoassay and an in vivo assay in Caenorhabditis elegans. J. Biol. Chem. 2012, 287, 27796-27805.

(40) Kai, T.; Zhang, L.; Wang, X.; Jing, A.; Zhao, B.; Yu, X.; Zheng, J.; Zhou, F. Tabersonine inhibits amyloid fibril formation and cytotoxicity of $\mathrm{A} \beta(1-42)$. ACS Chem. Neurosci. 2015, 6, $879-888$.

(41) Yang, F.; Lim, G-P.; Begum, A-N.; Ubeda, O-J.; Simmons, M-R.; Ambegaokar, S-S.; Chen, P-P.; Kayed, R.; Glabe, C-G.; Frautschy, S-A.; Cole, G-M. Curcumin inhibits formation of amyloid $\beta$ oligomers and fibrils, binds plaques, and reduces amyloid in vivo. J. Biol. Chem. 2005, 280, 5892-5901.

(42) (a) Smith, M.D.; Cruz, L. Changes to the structure and dynamics in mutations of A $\beta 21-30$ caused by ions in solution. J. Phys. Chem. B 2013, 117, 14907-14915. (b) Hochdörffer, K.; März-Berberich, J.; Nagel-Steger, L.; Epple, M.; Meyer-Zaika, W.; Horn, A.H.C.; Sticht, H.; Sinha, S.; Bitan, G.; Schrader, T. Rational design of $\beta$-sheet ligands against A $\beta 42$-induced toxicity. J. Am. Chem. Soc. 2011, 133, 4348-4358.

(43) Feng, Y.; Wanga, X.-P.; Yang, S.-G.; Wan, Y.-J.; Xi Zhang, Du, X.-T.; Sun, X.-X.; Zhao, M.; Huang, L.; Liu, R.-T. Resveratrol inhibits beta-amyloid oligomeric cytotoxicity but does not prevent oligomer formation. Neurotoxicology 2009, 30, 986-995. 
(44) Sinha, S.; Du, Z.; Maiti, P.; Klärner, F.-G.; Schrader, T.; Wang, C.; Bitan. G. Comparison of Three Amyloid Assembly Inhibitors: The sugar scyllo-inositol, the polyphenol epigallocatechin gallate, and the molecular tweezer CLR01. ACS Chem. Neurosci. 2012, 3, 451458.

(45) Hyunga, S.-J.; DeTomaa, A. S.; Brendera, J. R.; Leec, S.; Vivekanandana, S.; Kochia, A.; Choic, J.-S.; Ramamoorthya, A.; Ruotoloa, B. T.; Lima, M. H. Insights into anti-amyloidogenic properties of the green tea extract (-)-epigallocatechin-3-gallate toward metal-associated amyloid- $\beta$ species. Proc. Natl. Acad. Sci. USA. 2013, 110, 3743-3748.

(46) Bieschke, J.; Herbst, M.; Wiglenda, T.; Friedrich, R. P.; Boeddrich, A.; Schiele, F.; Kleckers, D.; Lopez del Amo, J. M.; Grüning, B. A.; Wang, Q.; Schmidt, M. R.; Lurz, R.; Anwyl, R.; Schnoeg, S.; Fändrich, M.; Frank, R. F.; Reif, B.; Günther, S.; Walsh, D. M.; Wanker, E. E. Small-molecule conversion of toxic oligomers to nontoxic $\beta$-sheet-rich amyloid fibrils. Nat. Chem. Biol. 2012, 8, 93-101. 
For Table of Contents Only

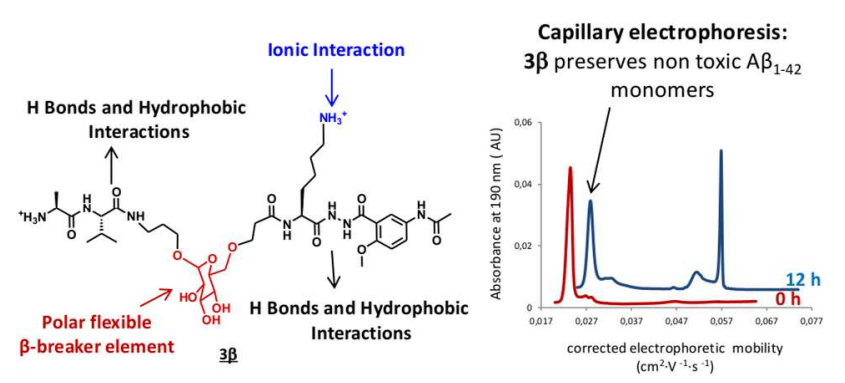

